\title{
PENGARUH KOMPENSASI, MOTIVASI, DAN LINGKUNGAN KERJA TERHADAP KEPUASAN KERJA KARYAWAN DI KONSULTAN PAJAK DRS. LIM YUNG SAN DAN REKAN
}

\author{
Alienda Retnosari P. \\ Institut Ilmu Sosial dan Manajemen STIAMI \\ allenpurwa@gmail.com
}

\begin{abstract}
Abstrak. Penelitian ini bertujuan untuk mengetahui pengaruh kompensasi, motivasi, dan lingkungan kerja terhadap kepuasan kerja karyawan. Penelitian ini menggunakan metode kuantitatif. Populasi penelitian seluruh karyawan Kantor Konsultan Pajak Drs. Lim Yung San dan Rekan sejumlah 30 orang. Teknik pengambilan sampel dengan adalah total sampling (sensus), sehingga jumlah sampel dalam penelitian ini adalah sesuai jumlah populasi karyawan. Analisa data menggunakan Regresi Linear Berganda. Hasil penelitian ditemukan kompensasi, motivasi dan lingkungan kerja secara simultan berpengaruh signifikan terhadap kepuasan kerja di Kantor Konsultan Pajak Drs. Lim Yung San dan Rekan. Oleh karena itu disarankan agar lebih dapat memperhatikan karyawannya melalui kompensasi, motivasi dan lingkungan kerja secara keseluruhan.
\end{abstract}

Kata Kunci: Kompensasi, Motivasi, dan Lingkungan Kerja.

Abstract. The aim of this research is to know the influence of compensation, motivation, and office environment toward the employee satisfaction on working. The method of this research is quantitative method. Double regression was used to analyze the data. The population of this research was all employees of Lim Yung San and Partner Tax Consultant. Sampling method is Total Sampling. The result of this research is compensation, motivation, and office environment have positive and significant effect toward the employee satisfaction to the employee of Lim Yung San and Partner Tax Consultant. Based on that result, the Tax Consultant have to concern to maintain the employee performance through the compensation, motivation, and office environment.

Keywords: Compensation, Motivation, and Office Environment.

\section{PENDAHULUAN}

Sumber daya manusia merupakan salah satu unsur atau bagian investasi terbesar dari suatu organisasi terutama bagi organisasi bisnis. Oleh karena itu banyak perusahaan yang mulai secara serius membangun dan mengembangkan sumber daya manusianya. Sumber daya manusia (SDM) yang berkualitas adalah sumber daya manusia yang memiliki kompetensi tinggi dan ketrampilan yang dapat memajukan perusahaan. Bagaimanapun juga perusahaan tidak akan mungkin dapat berjalan jika sumber daya manusia yang ada tidak mampu melaksanakan tugasnya dengan baik. Untuk itu faktor manusia memegang peranan utama dalam setiap usaha yang dilakukan perusahaan. Dengan kata lain keberhasilan sebuah perusahaan dalam melaksanakan kegiatan operasionalnya, tidak terlepas dari kualitas manajemen sumber daya manusia yang dimilikinya.

Kepuasan kerja karyawan yang tinggi dalam suatu perusahaan bukanlah perkara mudah sebab karakter karyawan yang heterogen dan dinamis acapkali menyulitkan perusahaan dalam mengatur dan mengarahkan potensi yang dimiliki masing-masing karyawan. Bila tidak diatur secara tepat, hal itu dapat berpengaruh pada rendahnya 
Alienda Retnosari P. Pengaruh Kompensasi, Motivasi, Dan Lingkungan Kerja Terhadap ...

kepuasan kerja karyawan sehingga menghambat pencapaian tujuan perusahaan. Untuk mengatasi hal tersebut, perusahaan dituntut agar lebih cermat dan teliti dalam menilai perkembangan masing-masing karyawan dengan memperhatikan faktorfaktor yang mempengaruhi kepuasan kerja tersebut. Sehingga perusahaan dapat menentukan sebab musabab rendahnya kepuasan kerja karyawan sekaligus menemukan jalan keluar yang konstruktif. Kepuasan kerja harus selalu diperhatikan dalam pencapaian tujuan perusahaan agar tidak menimbulkan suatu permasalahan seperti kompensasi, motivasi, dan lingkungan kerja.

Salah satu faktor yang dipandang memegang peranan penting dalam pencapaian kepuasan kerja adalah pemberian kompensasi. Setiap perusahaan menghendaki agar perusahaannya mempunyai kepuasan yang tinggi sehingga tujuan perusahaan dapat tercapai dengan baik. Masalah ini merupakan fungsi personalia yang sering dihadapi terutama bagaimana cara terbaik memberikan kompensasi yang sesuai dengan kebutuhan dan keinginan karyawan serta organisasi agar tidak ada pihak yang merasa dirugikan sehingga berdampak positif pada karyawan dan organisasi serta dapat mendongkrak kepuasan kerja.

Motivasi karyawan juga memiliki pengaruh penting terhadap kepuasan kerja. Seseorang cenderung bekerja dengan penuh semangat apabila kepuasan dapat diperolehnya dari pekerjaannya dan kepuasan kerja karyawan merupakan kunci pendorong moral, kedisiplinan dalam mendukung terwujudnya tujuan perusahaan. Betapapun sempurnanya rencana-rencana organisasi dan pengawasan, bila karyawan tidak dapat menjalankan tugasnya dengan minat dan gembira, maka suatu perusahaan tidak akan mencapai hasil sebanyak yang sebenarnya dapat dicapainya. Faktor manusia cukup berperan dalam pencapaian tujuan perusahaan. Karena karyawan yang puas akan bekerja dengan lebih baik dan produktif, sehingga perusahaan pada akhirnya akan dapat mencapai keunggulan bersaing.

Lingkungan kerja juga berperan penting dalam pencapaian kepuasan kerja dimana karyawan tersebut melaksanakan tugas dan tanggung jawabnya. Untuk mengoptimalkan kepuasan kerja karyawan makan harus tercipta lingkungan kerja yang kondusif sebagai prasyarat peningkatan kepuasan kerja yang maksimal. Lingkungan kerja yang tidak baik dapat berpengaruh buruk pada performance karyawan. Untuk itu, perusahaan dituntut untuk menciptakan lingkungan kerja yang baik dan kondusif bagi karyawan sesuai kompetensinya, sehingga karyawan dapat memberikan kemampuan terbaiknya demi kemajuan perusahaan.

Konsultan Pajak Drs. Lim Yung San dan Rekan merupakan perusahaan jasa yang khusus bergerak di bidang konsultasi perpajakan dengan pengalaman lebih dari 20 tahun. Terjadinya tingkat penampilan/performance kepuasan kerja karyawan Konsultan Pajak Drs. Lim Yung San dan Rekan yang kurang baik, sebagai suatu fenomena yang cenderung dilatarbelakangi oleh ketidakpuasan atas berbagai aspek keorganisasian dan manajerial di Konsultan Pajak Drs. Lim Yung San dan Rekan. Selama ini Kantor Konsultan Pajak Drs. Lim Yung San dan Rekan menerapkan sistem gaji bulanan serta tunjangan berupa uang makan yang diberikan setiap minggu, bonus bagi karyawan dengan kinerja memuaskan, selain itu juga rekreasi yang diadakan tiap tahun. Akan tetapi, karyawan merasa tidak ada kenaikan kompensasi finansial yang berarti atau tidak sesuai harapan setelah bertahun-tahun bekerja atau setidaknya setelah masa kerja dalam waktu tertentu seperti gaji. Selain itu tidak ada kompensasi penunjang lainnya yaitu jaminan kesehatan bagi karyawan. Karyawan atau keluarga karyawan yang sakit tidak bisa mendapatkan kompensasi kesehatan ini. Dengan demikian, karyawan merasa kompensasi yang ia peroleh dirasa kurang memenuhi kesejahteraannya. 
Lebih lanjut diketahui bahwa karyawan Kantor Konsultan Pajak ini merasa kurang bergairah dalam menjalankan tugas dan tanggung jawabnya yang disebabkan tingginya load pekerjaan tetapi kurang mendapat balas jasa yang diterima tidak sesuai harapan dan tidak ada peningkatan, ketat dan panjangnya jam kerja per hari terlebih di saat masa SPT Tahunan para karyawan diharuskan lembur. Kondisi tersebut mengakibatkan tingginya absensi serta hasil kerja yang kurang optimal serta membuat karyawan tidak merasa tertarik atau memiliki keinginan meningkatkan kinerjanya. Sistem pengukuran kehadiran (presensi) masih dilakukan secara manual dan pencatatan dilakukan oleh manajer HRD. Hal ini menimbulkan kendala dimana keakuratan data kehadiran masih dapat dimanipulasi dan tidak objektif, tidak dapat dipertanggungjawabkan, tidak sesuai dengan kehadiran yang semestinya dan menimbulkan rasa tidak puas terutama karyawan yang hadir lebih awal.

Faktor lain yang mempengaruhi kepuasan kerja adalah lingkungan kerja. Juga memperlihatkan bahwa adanya gap serta hubungan yang monoton antara atasan dengan bawahan yang diakibatkan oleh selisih pendapat. Keadaan lingkungan kerja seperti ini sangat mengganggu aktivitas kerja karyawan, menimbulkan rasa gelisah, serta kebosanan kerja. Fenomena dari uraian di atas dapat diketahui bahwa atau masalah yang terjadi cenderung karena belum terpenuhinya berbagai kebutuhan yang dianggap penting oleh karyawan. Dalam konteks ini, masalah yang paling substantif adalah keharusan untuk mengetahui dan menetapkan prioritas kebutuhan karyawan yang dapat dihubungkan dengan ciri karyawan itu sendiri.

Berdasarkan uraian identifikasi masalah di atas maka perumusan masalah sebagai berikut:

1. Apakah kompensasi berpengaruh terhadap kepuasan kerja karyawan Konsultan Pajak Drs. Lim Yung San dan Rekan?
2. Apakah motivasi berpengaruh terhadap kepuasan kerja karyawan Konsultan Pajak Drs. Lim Yung San dan Rekan?

3. Apakah lingkungan kerja berpengaruh terhadap kepuasan kerja karyawan Konsultan Pajak Drs. Lim Yung San dan Rekan?

4. Apakah pengaruh kompensasi, motivasi, dan lingkungan kerja secara bersamasama terhadap kepuasan kerja karyawan di Konsultan Pajak Drs. Lim Yung San dan Rekan?

\section{KAJIAN PUSTAKA \\ a. Kepuasan Kerja}

Tidak dapat disangkal bahwa manusia mempunyai kedudukan yang sangat penting dalam perusahaan. Manusia merupakan unsur manajemen sekaligus sumber daya perusahaan yang berperan dalam merencanakan, melaksanakan, dan bahkan mengawasi semua kegiatan perusahaan. Menyadari pentingnya kedudukan manusia dalam perusahaan, maka pemenuhan kebutuhannya juga menjadi hal yang sangat penting untuk diperhatikan khususnya mengenai kepuasan kerja karyawan. Robbins (2006: 103) mendefinisikan kepuasan kerja sebagai sikap umum individu terhadap pekerjaannya. Kepuasan kerja merupakan sikap umum individu terhadap pekerjaannya sehingga lebih mencerminkan sikap dari pada perilaku. Keyakinan bahwa karyawan yang puas lebih produktif daripada karyawan yang tidak puas menjadi prinsip dasar bagi para manajer maupun pimpinan.

Pengertian kepuasan kerja menurut Rivai dan Sagala (2009: 856) adalah evaluasi yang menggambarkan seseorang atas perasaan sikapnya senang atau tidak senang, puas atau tidak puas dalam bekerja. Kepuasan kerja adalah tingkat rasa puas individu dimana mereka merasa mendapat imbalan yang setimpal dari bermacam-macam aspek situasi pekerjaan dari organisasi tempat mereka bekerja.

Kepuasan kerja adalah keadaan emosional yang menyenangkan atau tidak menyenangkan bagi para pegawai 
memandang pekerjaan mereka. Kepuasan kerja mencerminkan perasaan seseorang terhadap pekerjaanya. Ini terlihat dalam sikap positif pegawai terhadap pekerjaan dan segala sesuatu yang dihadapi di lingkungan kerjanya. Departemen personalia atau manajemen harus senantiasa memonitor kepuasan kerja, karena hal tersebut mempengaruhi tingkat absensi, perputaran tenaga kerja, semangat kerja, keluhan dan masalah personalia vital lainnya (Sedarmayanti, 2007).

Berdasarkan beberapa paparan yang diberikan oleh para ahli tersebut dapat disimpulkan bahwa kepuasan kerja adalah cara individu merasakan pekerjaan (perasaan, sikap, ataupun persepsi) yang dihasilkan dari individu tersebut terhadap berbagai aspek yang terkandung dalam pekerjaan. Kepuasan kerja dapat juga dimaknai sebagai perasaan senang atau tidak senang, perasaan positif atau negatif, dan sikap-sikap emosional karyawan terhadap pekerjaannya.

Wexley dan Yukl dalam Riva'i (2005: 475) ada tiga macam yang lazim dikenal yaitu:

1. Teori Perbandingan Intrapersonal (Discrepancy Theory). Kepuasan atau ketidakpuasan yang dirasakan oleh individu merupakan hasil dari perbandingan atau kesenjangan yang dilakukan oleh diri sendiri terhadap berbagai macam hal yang sudah diperolehnya dari pekerjaan dan yang menjadi harapannya.

2. Teori Keadilan (Equity Theory). Seseorang akan merasa puas atau tidak puas tergantung apakah ia merasakan adanya keadilan atau tidak atas suatu situasi.

3. Teori Dua Faktor (Two Factor Theory). Prinsip dari teori ini adalah bahwa kepuasan dan ketidakpuasan kerja merupakan dua hal yang berbeda. Menurut teori ini, karakteristik pekerjaan dapat dikelompokkan menjadi dua kategori, yang satu dinamakan dissatisfier atau hygiene factors dan yang lain dinamakan satisfier atau motivator.
Robbins (2002: 181-182) menjabarkan variabel-variabel yang berkaitan dengan kerja yang menentukan kepuasan kerja, meliputi:

1. Kerja yang secara mental menantang. Karyawan cenderung lebih menyukai pekerjaan-pekerjaan yang memberi mereka kesempatan untuk menggunakan keterampilan dan kemampuan mereka dan menawarkan beragam tugas, kebebasan, dan umpan balik mengenai betapa baik mereka mengerjakannya.

2. Ganjaran yang pantas. Para karyawan menginginkan sistem upah dan kebijakan promosi yang mereka persepsikan sebagai adil dan segaris dengan pengharapan mereka. Bila upah dilihat sebagai adil yang didasarkan pada tuntutan pekerjaan, tingkat keterampilan individu, dan standar pengupahan komunitas, kemungkinan besar akan dihasilkan kepuasan kerja.

3. Kondisi kerja yang mendukung. Karyawan peduli akan lingkungan kerja yang baik untuk kenyamanan pribadi maupun untuk memudahkan mengerjakan tugas yang baik. Studi-studi menunjukkan bahwa karyawan lebih menyukai keadaan fisik sekitar yang tidak berbahaya atau merepotkan.

4. Rekan sekerja yang mendukung. Bagi kebanyakan karyawan, kerja juga mengisi kebutuhan akan interaksi sosial. Oleh karena itu, tidaklah mengejutkan bila mempunyai rekan sekerja yang ramah dan mendukung menghantar ke kepuasan kerja yang meningkat.

Ada konsekuensi ketika karyawan menyukai pekerjaan mereka dan ada konsekuensi ketika karyawan tidak menyukai pekerjaan mereka. Robbins (2008: 111-112) menjabarkan tentang respon-respon tersebut sebagai berikut:

1. Keluar (exit): perilaku yang ditunjukkan untuk meninggalkan organisasi, termasuk untuk mencari posisi baru, dan mengundurkan diri.

2. Aspirasi (voice): secara aktif dan variabeltif berusaha memperbaiki kondisi, termasuk menyarankan 
perbaikan, mendiskusikan masalah dengan atasan, dan beberapa bentuk aktivitas serikat pekerja.

3. Kesetiaan (loyalty): secara pasif tetapi optimis menunggu membaiknya kondisi, termasuk membela organisasi ketika berhadapan dengan ancaman eksternal dan mempercayai organisasi dan manajemennya untuk "melakukan hal yang benar".

4. Pengabaian (Neglect): secara pasif membiarkan kondisi menjadi lebih buruk, termasuk ketidakhadiran dan keterlambatan yang terus-menerus, kurangnya usaha, dan meningkatnya angka kesalahan.

Cara yang dapat dilakukan untuk meningkatkan kepuasan kerja berdasarkan Greenberg dan Baron (2003: 159):

1. Make Jobs Fun. Orang akan lebih puas dengan pekerjaan yang mereka nikmati daripada yang membosankan. Walaupun beberapa pekerjaan memang bersifat membosankan, tetap ada beberapa cara untuk menyuntikkan beberapa level ke dalam setiap pekerjaan.

2. Pay People Fairly. Ketika orang merasa bahwa mereka dibayar atau diberi imbalan secara adil, maka kepuasan kerja mereka cenderung akan meningkat.

3. Match People to Jobs That Fit Their Interests. Semakin orang merasa bahwa mereka mampu memenuhi kesenangan atau minat mereka saat bekerja, semakin mereka akan mendapatkan kepuasan dari pekerjaan tersebut.

4. Avoid Boring Repetitive Jobs. Orang jauh lebih merasa puas terhadap pekerjaan yang memungkinkan mereka untuk mencapai keberhasilan dengan memiliki kontrol secara bebas tentang bagaimana mereka melakukan tugas-tugas mereka.

Untuk membantu mengetahui seberapa besar kemampuan seseorang mendapatkan tingkat kepuasan kerja, maka ada beberapa dimensi yang dapat diukur yang dijadikan sebagai tolak ukur kepuasan kerja. Luthans (2011: 141) menyebutkan beberapa dimensi kepuasan kerja, yaitu:
1. Pekerjaan itu sendiri (work itself). Sejauh mana tugas-tugas pekerjaan yang dianggap menarik kesempatan untuk belajar, dan kesempatan untuk menerima tanggung jawab.

2. Upah (payment). Jumlah remunerasi keuangan yang diterima dan sejauh mana hal ini dipandang sebagai adil orang lain dalam organisasi.

3. Peluang promosi (promotion opportunities). Kemungkinan untuk kemajuan dalam organisasi.

4. Pengawasan (supervision). Kemampuan supervisor untuk memberikan bantuan teknis dan dukungan perilaku.

5. Rekan kerja (coworkers). Sejauh mana sesama pekerja ahli teknis dan mendukung secara social.

\section{b. Kompensasi}

Kebijaksanaan kompensasi merupakan penting dan strategis, karena langsung berhubungan dengan peningkatan semangat kerja, kepuasan kerja, dan motivasi pegawai dalam suatu organisasi. Kompensasi adalah seluruh balas jasa baik berupa uang, barang ataupun kenikmatan yang diberikan oleh perusahaan kepada pegawai atas prestasi kerja yang disumbangkan kepada perusahaan (Gorda, 2006).

Milkovich dan Newman (2005: 6), mendefinisikan kompensasi sebagai berikut "kompensasi mengacu pada semua bentuk, pengembalian keuangan dan jasa dan manfaat yang nyata karyawan menerima sebagai bagian dari hubungan kerja." Werther dan Davis (2007:134) mendefinisikan kompensasi sebagai apa yang diterima pekerja sebagai tukaran atas kontribusinya kepada organisasi. Adapula yang menyatakan kompensasi adalah segala sesuatu yang diterima para karyawan sebagai balas jasa untuk mereka (Handoko, 2001).

Definisi-definisi di atas dapat disimpulkan bahwa kompensasi merupakan segala sesuatu yang diterima karyawan sebagai konsekuensi kontribusi kinerja mereka pada perusahaan yang berupa finansial (langsung: berupa gaji, upah, komisi, 
insentif dan tak langsung berupa asuransi kesehatan, cuti dan fasilitas lainnya) maupun nonfinansial (berupa kebijakan, pekerjaan tambahan dan lingkungan kerja yang nyaman). Istilah kompensasi sering digunakan secara bergantian dengan administrasi, gaji dan upah. Kompensasi merupakan konsep yang lebih luas. Kompensasi diartikan sebagai semua bentuk kembalian atau imbalan (return) finansial, jasa-jasa berwujud dan tujuan-tujuan yang diperoleh karyawan sebagai dari sebuah hubungan kepegawaian.

Hasibuan (2008), menyatakan bahwa sistem kompensasi yang sering diterapkan sebagai berikut:

1. Sistem waktu. Dalam sistem ini ditetapkan berdasarkan standar waktu seperti jam, minggu, atau bulan. Sistem waktu dapat dengan mudah diterapkan pada pegawai tetap atau pegawai harian.

2. Sistem hasil. Dalam sistem hasil atau output ini, kompensasi ditetapkan atas kesatuan unit yang dihasilkan pekerja, seperti per potong, meter, liter dan kilogram. Sistem ini cocok untuk pegawai di bagian produksi barang.

3. Sistem borongan. Suatu cara pengupahan yang penetapan besarnya jasa didasarkan atas volume pekerjaan dan lama mengerjakannya, serta banyak alat yang diperlukan untuk menyelesaikannya.

Dalam menentukan kebijakan pemberian kompensasi, perusahaan tentunya memiliki tujuan tertentu yang berkaitan dengan pengelolaan SDM-nya. Tujuan pemberian kompensasi menurut Hasibuan (2008: 121122) adalah:

1. Ikatan Kerja Sama. Dengan pemberian kompensasi terjalin ikatan kerjasama formal majikan dengan karyawan.

2. Kepuasan Kerja. Dengan balas jasa, karyawan akan dapat memenuhi kebutuhan-kebutuhan fisik, status sosial dan egoistiknya sehingga memperoleh kepuasan kerja dari jabatannya.

3. Pengadaan Efektif. Jika program kompensasi ditetapkan cukup besar, pengadaan karyawan yang qualified untuk perusahaan akan lebih mudah.
4. Motivasi. Jika balas jasa yang diberikan cukup besar, manajer akan mudah memotivasi bawahannya.

5. Stabilitas Karyawan. Dengan program kompensasi atas prinsip adil dan layak serta eksternal konsistensi yang kompetitif maka stabilitas karyawan lebih terjamin karena turn-over relatif kecil.

6. Disiplin. Pemberian balas jasa yang cukup besar maka disiplin karyawan semakin baik. Mereka akan menyadari dan menaati peraturan-peraturan yang berlaku.

7. Pengaruh Serikat Buruh. Dengan program kompensasi yang baik pengaruh serikat buruh dapat dihindarkan dan karyawan akan berkonsentrasi pada pekerjaannya.

8. Pengaruh Pemerintah. Jika program kompensasi sesuai dengan undangundang perburuhan yang berlaku (seperti batas upah minimum), maka intervensi pemerintah dapat dihindarkan.

Komponen-komponen kompensasi dapat berupa kompensasi tidak langsung (indirect compensation) dan kompensasi finansial langsung (direct financial) terdiri dari bayaran (pay) yang diperoleh seseorang dalam bentuk gaji, upah, dan komisi. Kompensasi finansial tidak langsung yang disebut juga dengan tunjangan, meliputi semua imbalan finansial yang tidak tercakup dalam kompensasi langsung (Simamora, 2006). Kompensasi non finansial terdiri dari kepuasan yang diperoleh seseorang dari pekerjaan itu sendiri, atau dari lingkungan psikologis dan atau fisik dimana orang tersebut bekerja.

1. Financial Compensation (Kompensasi Finansial). Artinya kompensasi yang diwujudkan dengan sejumlah uang kartal kepada karyawan yang bersangkutan dan dibedakan menjadi 2 (dua), yaitu :

\section{a. Direct Financial Compensation} (Kompensasi Finansial Langsung). Adalah pembayaran berbentuk uang yang karyawan terima secara langsung dalam bentuk gaji/upah, tunjangan ekonomi, bonus dan komisi. 
b. Indirect Financial Compensation (Kompensasi Finansial Tak Langsung). Adalah termasuk semua penghargaan keuangan yang tidak termasuk kompensasi langsung. Wujud kompensasi meliputi program asuransi tenaga kerja (Jamsostek), pertolongan sosial, pembayaran biaya sakit (berobat), cuti dan lainlain.

2. Non-Financial

Compensation

(Kompensasi Non Finansial). Adalah balas jasa yang diberikan perusahaan kepada karyawan bukan berbentuk uang, tapi berwujud fasilitas. Kompensasi jenis ini dibedakan menjadi 2 (dua), yaitu:

a. Non-Financial the Job (Berkaitan Dengan Pekerjaan) berupa pekerjaan yang menarik, kesempatan untuk berkembang, pelatihan, wewenang dan tanggung jawab, penghargaan atas kinerja. Kompensasi bentuk ini merupakan perwujudan dari pemenuhan kebutuhan harga diri dan aktualisasi.

b. Non-Financial Job Environment (Berkaitan Dengan Lingkungan Pekerjaan) mengenai lingkungan pekerjaan berupa supervisi kompetensi, kondisi kerja yang mendukung, dan pembagian kerja (Mondy, 2003: 442).

Gary Dessler menerangkan kompensasi mempunyai tiga komponen sebagai berikut:

a. Pembayaran uang secara langsung (direct financial payment) dalam bentuk gaji dan insentif atau bonus/komisi.

b. Pembayaran tidak langsung (indirect payment) dalam bentuk tunjangan dan asuransi.

c. Ganjaran non finansial (non-financial rewards) seperti jam kerja yang luwes dan kantor yang bergengsi.

Berdasarkan berbagai pendapat, dapat disimpulkan kompensasi dibagi berdasarkan bentuk dan cara pemberian.

Gorda (2006: 65) melihat ada tiga wujud kompensasi, yaitu: a. Kompensasi yang berbentuk uang seperti upah dan gaji, bonus, uang lembur, tunjangan pangan yang dibayar dengan uang, dan sebagainya.

b. Kompensasi yang berwujud barang seperti tunjangan pangan yang dibayar dengan beras, tunjangan lauk-pauk yang dibayar dengan lauk-pauk dan sebagainya.

c. Kompensasi berwujud kenikmatan seperti penghargaan (pengakuan pencapaian hasil kerja), promosi, perumahan dengan sewa murah, transportasi dengan sewa murah, pelayanan kesehatan gratis, dan sebagainya.

Menurut Mello (2006: 494) istilah kompensasi dibagi atas 2 (dua) bagian, yaitu:

a. Kompensasi langsung (direct) seperti gaji atau upah (base pay) berupa bayaran tetap atau insentif (incentive pay) berupa bonus, komisi, bagian perolehan laba, dan lain-lain.

b. Kompensasi tidak langsung (indirect) berupa aturan (legally required) yakni jaminan sosial, jaminan hidup kesehatan keluarga, dan lain-lain. Juga atas dasar pilihan (optional) berupa liburan khusus, cuti, dana pensiun, asuransi hari tua, dan lain-lain.

\section{c. Motivasi}

Motivasi berasal dari kata motivation, yang artinya dorongan daya batin. Sedangkan to motivate artinya mendorong untuk berperilaku atau berusaha. Motivasi dalam manajemen, lebih menitikberatkan pada bagaimana cara mengarahkan daya dan potensi bawahan, agar mau bekerja sama secara produktif berhasil mencapai dan mewujudkan tujuan yang telah ditentukan. Sadili Samsuddin (2006: 281) memberikan pendapat tentang pengertian motivasi yaitu proses mempengaruhi atau mendorong dari luar terhadap seseorang atau kelompok kerja agar mereka mau melaksanakan sesuatu yang telah ditetapkan.

Motivasi adalah proses yang menjelaskan intensitas, arah dan ketekunan seorang individu untuk mencapai tujuan (Robbins, 
Alienda Retnosari P. Pengaruh Kompensasi, Motivasi, Dan Lingkungan Kerja Terhadap ...

2006). Tiga elemen utama dalam definisi tersebut adalah intensitas berhubungan dengan seberapa giat seseorang berusaha, arah merupakan tujuan sedangkan ketekunan merupakan ukuran mengenai berapa lama seseorang bisa mempertahankan usahanya. Pentingnya motivasi karena motivasi adalah hal yang menyebabkan, menyalurkan dan mendukung perilaku manusia, supaya mau bekerja giat dan antusias untuk mencapai hasil yang optimal. Motivasi semakin penting karena manajer membagikan pekerjaan pada bawahannya untuk dikerjakan dengan baik dan terintegrasi kepada tujuan yang diinginkan.

Pendapat lain mengenai motivasi menurut Buhler (2004), motivasi pada dasarnya adalah proses yang menentukan seberapa banyak usaha yang akan dicurahkan untuk melaksanakan pekerjaan. Motivasi atau dorongan untuk bekerja ini sangat menentukan bagi tercapainya sesuatu tujuan, maka manusia harus dapat menumbuhkan motivasi kerja setinggi-tingginya bagi para karyawan dalam perusahaan.

Malthis (2006: 114) menerangkan bahwa motivasi adalah keinginan dalam diri seseorang yang menyebabkan orang tersebut bertindak. Biasanya orang bertindak karena suatu alasan untuk mencapai tujuan. Menurut Terry (2009: 130) motivasi menyangkut soal perilaku manusia dan merupakan elemen vital dalam manajemen. Motivasi dapat diartikan mengusahakan supaya seseorang dapat menyelesaikan pekerjaan dengan semangat karena dia ingin melaksanakannya. Manusia memiliki motivasi yang berbeda tergantung dari banyak faktor seperti kepribadian dan ambisi. Seseorang yang termotivasi menunjukkan usaha dan bekerja keras (Robbins dan Coulter, 2010: 109). Sedangkan definisi menurut Hasibuan (2003), motivasi merupakan dorongan karyawan atau sikap mental karyawan yang mengarah atau mendorong perilaku kearah pencapaian kebutuhan yang memberikan kepuasan.

Menurut Rivai (2004:455-456), motivasi kerja adalah serangkaian sikap dan nilai-nilai yang mempengaruhi individu untuk mencapai hal yang spesifik sesuai dengan tujuan individu. Sikap dan nilai tersebut merupakan suatu yang invisible yang memberikan kekuatan untuk mendorong individu bertingkah laku dalam mencapai tujuan. Apabila individu termotivasi, maka individu akan membuat pilihan yang positif untuk melakukan sesuatu karena dapat memuaskan keinginannya. Sedangkan menurut Robbins (2002:199), motivasi kerja diartikan sebagai kesediaan untuk mengeluarkan tingkat upaya yang tinggi ke arah tujuan-tujuan organisasi, yang dikondisikan oleh kemampuan upaya itu untuk memenuhi suatu kebutuhan individual. Kebutuhan dalam hal ini berarti suatu keadaan internal yang menyebabkan hasilhasil tertentu tampak menarik. Suatu kebutuhan yang tak terpuaskan menciptakan tegangan yang merangsang dorongandorongan dalam diri individu. Dorongan ini menimbulkan suatu perilaku pencarian untuk menemukan tujuan-tujuan tertentu yang jika tercapai akan memenuhi kebutuhan itu dan mendorong ke pengurangan tegangan.

Beberapa teori mengenai motivasi antara lain teori hierarki kebutuhan (hierarchy of needs) milik Abraham Maslow, Teori $\mathrm{X}$ dan Y, serta teori dua faktor (Robbins, 2006):

1. Teori hierarki kebutuhan (hierarchy of needs) milik Abraham mengemukakan lima tingkat kebutuhan yaitu:

a. Kebutuhan fisiologis (Phisiological) meliputi rasa lapar, haus, tempat tinggal, seksual, dan kebutuhan fisik lainnya.

b. Kebutuhan akan rasa aman (safety) meliputi rasa ingin dilindungi dari bahaya fisik dan emosional.

c. Kebutuhan sosial (social) meliputi rasa kasih sayang, kepedulian penerimaan dan persahabatan.

d. Kebutuhan akan penghargaan (esteem) meliputi faktor-faktor penghargaan internal seperti penghormatan diri, otonomi dan pencapaian. Untuk faktor-faktor penghargaan eksternal seperti status dan pengakuan. 
e. Kebutuhan aktualisasi diri (selfactualization) yaitu dorongan untuk menjadi seseorang sesuai kecakapannya meliputi pertumbuhan, pencapaian potesi seseorang dan pemenuhan diri sendiri.

2. Teori $\mathrm{X}$ dan $\mathrm{Y}$ dari Dauglas McGregor mengemukakan mengenai manusia, pertama negatif disebut Teori $\mathrm{X}$ dan kedua positif disebut teori Y. Menurut teori $\mathrm{X}$ ada empat asumsi yang dimiliki manajer adalah:

a. Pada dasarnya karyawan tidak menyukai pekerjaan sebisa mungkin menghindari.

b. Karena karyawan tidak menyukai pekerjaan mereka harus dipaksa, dikendalikan atau diancam dengan hukuman untuk mencapai tujuan.

c. Karyawan akan menghindari tanggung jawab dan mencari perintah formal bila mungkin

d. Sebagai karyawan menempatkan keamanan di atas semua faktor lain terkait pekerjaan dan menunjukkan sedikit ambisi.

Sedangkan menurut teori $\mathrm{Y}$ ada empat asumsi positif yaitu:

a. Karyawan menganggap kerja sebagai hal yang menyenangkan seperti halnya istirahat atau bermain

b. Karyawan akan berlatih mengendalikan diri dan emosi untuk mencapai tujuan

c. Karyawan bersedia belajar untuk menerima, bahkan mencari, dan tanggung jawab

d. Karyawan mampu membuat berbagai keputusan inovatif yang diedarkan ke seluruh populasi dan bukan hanya bagi mereka yang menduduki posisi manajemen.

3. Teori Dua Faktor juga disebut teori motivasi higiene dikemukakan oleh Frederick Herzberg. Dengan keyakinan bahwa hubungan seorang individu dengan pekerjaan mendasar dan bahwa sikap seseorang terhadap pekerjaan bisa dengan sangat baik menentukan keberhasilan atau kegagalan. Tiga aspek yang sangat penting dari hubungan perilaku-hasil adalah sebagai berikut:

a. Harapan usaha-kinerja merujuk pada keyakinan karyawan bahwa bekerja lebih keras akan menghasilkan kinerja. Apabila orang tidak percaya bahwa bekerja lebih keras menghasilkan kinerja, usaha mereka mungkin berkurang.

b. Hubungan kinerja-penghargaan mempertimbangkan harapan individu bahwa kinerja yang tinggi benarbenar akan menghasilkan penghargaan. Hubungan kinerjapenghargaan mengindikasikan bagaimana kinerja efektif yang instrumental atau penting membuahkan hasil yang diinginkan.

c. Nilai penghargaan merujuk pada seberapa bernilainya penghargaan bagi karyawan. Satu faktor yang menentukan kesediaan karyawan untuk mengarahkan usahanya adalah tingkat sampai mana mereka menilai penghargaan yang diberikan oleh organisasi.

Dalam teori ERG (Daft, 2006: 369), mengusulkan modifikasi teori Maslow sebagai usaha untuk menyederhanakan dan merespon akan kurangnya verifikasi yang empiris. Teori ERG mengidentifikasikan tiga kategori kebutuhan:

1. Kebutuhan kehidupan (existence needs). Merupakan kebutuhan-kebutuhan akan kesejahteraan fisik.

2. Kebutuhan keterhubungan (relatedness needs). Menyinggung kebutuhan pemenuhan hubungan dengan orang lain.

3. Kebutuhan pertumbuhan (growth needs). Ini berfokus pada perkembangan potensi manusia dan keinginan akan pertumbuhan pribadi serta kompetensi yang meningkat.

Menurut Maslow (Daft, 2006: 367), indikator motivasi adalah:

1. Kebutuhan fisiologis, merupakan kebutuhan-kebutuhan fisik manusia yang 
Alienda Retnosari P. Pengaruh Kompensasi, Motivasi, Dan Lingkungan Kerja Terhadap ...

paling dasar, termasuk makanan, air, dan oksigen.

2. Kebutuhan akan rasa aman, merupakan kebutuhan akan lingkungan fisik dan emosional yang aman dan terlindung dari ancaman-ancaman yaitu kebutuhan akan kebebasan dari kekuasaan, dan masyarakat yang tertib.

3. Kebutuhan akan sosial, kebutuhan ini mencerminkan keinginan untuk diterima oleh teman-teman, menjalin persahabatan, menjadi bagian dari suatu kelompok, dan dicintai.

4. Kebutuhan akan penghargaan, kebutuhan-kebutuhan ini berkenaan dengan keinginan akan kesan diri yang positif dan untuk menerima perhatian, pengakuan, dan apresiasi dari orang lain.

5. Kebutuhan aktualisasi diri, ini mempresentasikan kebutuhan pemenuhan diri, yang merupakan kategori kebutuhan tertinggi. Kebutuhan tersebut berkenaan dengan mengembangkan potensi maksimal seseorang, meningkatkan kompetensi seseorang, dan menjadi seseorang yang lebih baik.

\section{d. Lingkungan Kerja}

Lingkungan kerja merupakan salah satu faktor dari fungsi Manajemen SDM, tepatnya fungsi perencanaan. Fungsi ini berhubungan langsung dengan pegawai yang bekerja pada lingkungan organisasi. Lingkungan kerja dalam suatu perusahaan sangat penting untuk diperhatikan oleh manajemen. Meskipun lingkungan kerja tidak melaksanakan proses produksi dalam suatu perusahaan, namun lingkungan kerja mempunyai pengaruh langsung terhadap para karyawan yang melaksanakan proses produksi tersebut.

Menurut Alex S Nitisemito (2000: 183) mendefinisikan lingkungan kerja sebagai segala sesuatu yang ada di sekitar para pekerja yang dapat mempengaruhi dirinya dalam menjalankan tugas-tugas yang diemban. Pengertian lain dari Sedarmayati (2001: 1) mengemukakan lingkungan kerja adalah keseluruhan alat perkakas dan bahan yang dihadapi, lingkungan sekitarnya dimana seseorang bekerja, metode kerjanya, serta pengaturan kerjanya baik sebagai perseorangan maupun sebagai kelompok.

Kondisi lingkungan kerja yang berbeda pada setiap organisasi dapat memberikan tingkat kepuasan yang berbeda pula bagi karyawan, sehingga prestasi kerja dalam menyelesaikan tugas yang dibebankan padanya juga berbeda. Yang harus diusahakan untuk memperbaiki metode kerja dalam suatu organisasi atau tempat kerja yang lain adalah menjamin agar para karyawan dapat bekerja dan melaksanakan tugasnya dalam keadaan yang memenuhi persyaratan, sehingga mereka dapat melakukan tugasnya tanpa mengalami hambatan. Lingkungan kerja yang memuaskan para karyawan akan mendorong para karyawan untuk bekerja dengan sebaikbaiknya, hal ini terjadi karena dengan adanya lingkungan yang baik akan membuat prestasi kerja karyawan tersebut meningkat, sehingga ia dapat menyelesaikan tugas yang dibebankan kepadanya dengan baik.

Menurut Hermino (2013: 15) lingkungan kerja dibedakan menjadi lingkungan fisik dalam arti semua keadaan yang terdapat di sekitar tempat kerja akan mempengaruhi pegawai baik secara langsung, misalnya pusat kerja, kursi, meja, maupun secara tidak langsung misalnya rumah, kantor, sekolah, sistem, jalan raya, dan kendaraan. Selain lingkungan fisik ada juga lingkungan perantara misalnya temperatur, kelembaban, sirkulasi udara, pencahayaan, kebisingan, bau tak sedap, warna, dan sebagainya. Menurut Wirawan (2007: 122), lingkungan kerja dalam organisasi adalah persepsi anggota organisasi (secara individual dan kelompok) dan mereka yang secara tetap berhubungan dengan organisasi (misalnya pemasok, konsumen, konsultan, dan kontraktor) mengenai apa yang ada atau terjadi di lingkungan internal organisasi secara rutin, yang mempengaruhi sikap dan perilaku organisasi yang kemudian menentukan kinerja anggota dalam organisasi tersebut.

Menurut Neal dan Griffin (2008: 100), lingkungan kerja didefinisikan dengan konstruksi multidimensional yang 
memberikan petunjuk pada rentangan atau jangkauan yang luas terhadap evaluasievaluasi individu di dalam lingkungan kerja. Berkaitan dengan pengertian lingkungan kerja yang meliputi aspek iklim dalam bekerja di dunia usaha dan dunia industri, Adenike menjelaskan lingkungan kerja berfungsi sebagai ukuran dari persepsi individu atau perasaan seseorang tentang suatu organisasi. Lingkungan kerja, menurut Adenike (2011:152) meliputi gaya manajemen atau kepemimpinan, partisipasi dalam pengambilan keputusan, pemberian pekerjaan yang menantang untuk karyawan, pengurangan kebosanan dan frustrasi, ketentuan bagi keuntungan, kebijakan personil, penyediaan kondisi kerja yang baik dan penciptaan tahapan karir yang cocok untuk akademisi.

Menurut Wursanto (2003: 301), indikator dari lingkungan kerja meliputi:

1. Kondisi kerja. Dikatakan baik apabila memungkinkan seseorang untuk meningkatkan produktivitas kerjanya, baik kondisi fisik maupun kondisi psikologis.

2. Keamanan dalam pekerjaan. Adalah terjaminannya keselamatan kerja selama melaksanakan tugas. Pada dasarnya setiap karyawan menghendaki jaminan keselamatan kerja.

Sedarmayanti (2006:97) menyatakan bahwa secara garis besar, jenis lingkungan kerja terbagi menjadi 2 (dua) yakni lingkungan kerja fisik, dan lingkungan kerja non fisik. Lingkungan kerja fisik diantaranya adalah penerangan/cahaya, temperatur/suhu udara, kelembaban, sirkulasi udara, kebisingan, getaran inmekanis, bau tidak sedap, tata warna, dekorasi, musik dan keamanan di tempat kerja. Sedangkan lingkungan kerja non fisik diantaranya adalah hubungan sosial di tempat kerja baik antara atasan dengan bawahan atau hubungan antara bawahan.

Mangkunegara (2005:105), menyatakan bahwa ada beberapa jenis lingkungan kerja, yaitu:
1. Kondisi lingkungan kerja fisik yang meliputi:

a. Faktor lingkungan tata ruang kerja yang baik akan mendukung terciptanya hubungan kerja yang baik antara sesama karyawan maupun dengan atasan karena mempermudah mobilitas bagi karyawan untuk bertemu.

b. Ruang kerja yang bersih, rapi, sehat dan aman akan menimbulkan rasa nyaman dalam bekerja. Hal ini akan meningkatkan gairah dan semangat kerja karyawan.

2. Kondisi lingkungan kerja non fisik yang meliputi:

a. Faktor lingkungan sosial yang sangat berpengaruh terhadap kinerja karyawan adalah latar belakang keluarga, yaitu antara lain status keluarga, jumlah keluarga, tingkat kesejahteraan dan lain-lain.

b. Faktor status sosial. Semakin tinggi jabatan seseorang semakin tinggi pula kewenangan dan keleluasaan dalam mengambil keputusan.

c. Faktor hubungan kerja dalam perusahaan. Hubungan kerja yang ada dalam perusahaan adalah hubungan kerja antara karyawan dengan karyawan dan antara karyawan dengan atasan.

d. Faktor sistem informasi. Hubungan kerja akan dapat berjalan dengan baik apabila ada komunikasi yang baik diantara anggota perusahaan maka akan berinteraksi, saling memahami, saling mengerti satu sama lain.

3. Kondisi psikologis dari lingkungan kerja yang meliputi:

a. Rasa bosan. Kebosanan kerja dapat disebabkan perasaan yang tidak enak, kurang bahagia, kurang istirahat dan perasaan lelah.

b. Keletihan dalam bekerja. Keletihan kerja terdiri atas dua macam yaitu keletihan kerja psikis dan keletihan psikologis yang dapat menyebabkan 
meningkatkan absensi, turn over, dan kecelakaan.

\section{METODE PENELITIAN}

Jenis penelitian dalam tipe penelitian survei yang dimaksudkan untuk memberikan penjelasan. Survei juga merupakan studi yang dilakukan dengan metode kuantitatif (quantitative method). Yaitu suatu penelitian yang memerlukan statistik sebagai alat serta meneliti gejala suatu kelompok atau perilaku individu, pengetahuan, kemauan, pendapat, perilaku dan nilai (Supranto, 2012: 47). Penggalian pengumpulan data dan informasi diambil dari populasi yang menjadi obyek penelitian dan menarik sampel dari populasi yang ada dengan menggunakan kuesioner kemudian dianalisa untuk memperhitungkan pengaruh lebih dari satu variabel bebas $X$ agar mendapatkan data yang akurat tentang faktafakta serta pengaruh antara variabel penelitian dengan analisis regresi linear berganda. Data pendukung lainnya diperoleh melalui kuesioner, wawancara, observasi maupun data dokumentasi.

Dalam konteks penelitian ini, survei dilakukan agar dapat menghasilkan data yang valid untuk kemudian dikaji dari pengaruh tiga variabel bebas (independen) yaitu kompensasi, motivasi, dan lingkungan kerja terhadap satu variabel terikat (dependen) yaitu kepuasan kerja. Selanjutnya, penilaian yang dilakukan menggunakan skala likert yang menurut Sarjono dan Julianita (2011), skala likert adalah skala yang digunakan untuk mengukur sikap, pendapat dan persepsi seseorang atau sekelompok orang terhadap suatu kejadian atau keadaan sosial, dimana variabel yang akan diukur dijabarkan menjadi indikator variabel, kemudian indikator tersebut dijadikan sebagai titik tolak untuk menyusun item-item pernyataan. Model skala likert dalam instrumen terdiri dari lima alternatif jawaban yang telah disediakan yaitu (5) sangat setuju, (4) setuju, (3) ragu-ragu, (2) tidak setuju, dan (1) sangat tidak setuju.

Populasi dan sampel dalam penelitian adalah seluruh karyawan di Konsultan Pajak Drs. Lim Yung San dan Rekan yang berjumlah 30 orang. Teknik pengambilan sampel dalam penelitian ini adalah total sampling (sensus), yaitu teknik pengambilan sampel dimana jumlah sampel sama dengan populasi. Adapun jenis data yang dipergunakan dalam penelitian ini (Supranto, 2012: 401) sebagai berikut terdiri dari:

1. Data primer, merupakan data yang diperoleh secara langsung dari responden penelitian dalam hal ini adalah karyawan kantor Konsultan Pajak Drs. Lim Yung San dan Rekan.

2. Data sekunder, merupakan data dalam bentuk kepustakaan, arsip, dan pengamatan di Konsultan Pajak Drs. Lim Yung San dan Rekan.

Untuk metode analisis data yang dapat dilakukan menurut Supranto (2012: 154), pada dasarnya diartikan:

1. Membandingkan dua hal atau dua nilai variabel untuk mengetahui selisih atau rasio kemudian diambil kesimpulan.

2. Menguraikan atau memecahkan suatu keseluruhan menjadi bagian atau komponen yang lebih kecil, agar dapat:
a. Mengetahui komponen yang menonjol (mempunyai nilai ekstrem).

b. Membandingkan antara komponen yang satu dengan lainnya (dengan menggunakan angka rasio atau selisih).

c. Membandingkan salah satu atau beberapa komponen dengan keseluruhan (dengan menggunakan persentase).

d. Memperkirakan atau memperhitungkan besarnya pengaruh secara kuantitatif dari perubahan suatu (beberapa) kejadian terhadap suatu (beberapa) kejadian lainnya serta memperkirakan/meramalkan kejadian lainnya. Kejadian (event) dapat dinyatakan sebagai perubahan nilai variabel.

Untuk uji instrumen dapat dilakukan dengan dua model yakni uji validitas, uji reliabilitas, dan uji asumsi klasik. Uji validitas 
menurut Supranto (2010: 4) merupakan alat ukuran dikatakan valid (sahih) kalau bisa mengukur apa yang seharusnya diukur. Timbangan yang rusak, pertanyaan yang tidak jelas merupakan alat ukur yang tidak sahih (not valid). Tipe validitas yang digunakan adalah validitas konstruk yang menentukan validitas dengan cara mengkorelasikan antar skor yang diperoleh masing-masing item yang dapat berupa pertanyaan maupun pertanyaan dengan skor totalnya. Uji validitas item atau butir dapat dilakukan dengan menggunakan software SPSS. Uji reliabilitas untuk mengetahui tingkat konsistensi hasil pengukuran jika dilakukan pengukuran ulang gejala dan alat ukur yang sama. Reliable artinya dapat dipercaya jadi dapat diandalkan. (Arikunto, (2002: 154) dalam Supranto dan Limakrisna, 2013: 99). Menghitung uji reliabilitas juga dengan bantuan software SPSS.

Uji asumsi klasik dilakukan sebelum pengujian hipotesis, perlu dilakukan pengujian-pengujian terhadap gejala penyimpangan asumsi klasik. Asumsi model linear klasik adalah tidak terdapat multikolinieritas, heteroskedasitas dan data terdistribusi secara normal (Ghozali, 2009). Uji multikolinieritas menurut Supranto dan Limakrisna, (2013: 160), dapat dideteksi dengan menghitung koefisien korelasi ganda dan membandingkannya dengan koefisien korelasi antar variabel bebas. Uji heterokedastisitas menurut Supranto dan Limakrisna, (2013: 163) terjadi dalam regresi apabila varian error untuk beberapa nilai $\mathrm{x}$ tidak konstan atau berubah-ubah. Sedangkan uji normalitas menurut Supranto dan Limakrisna (2013: 91) dilakukan dengan teknik uji kenormalan sehingga hasil dapat berdistribusi normal. Seluruhnya menggunakan software SPSS.

Analisis data yang dipergunakan adalah regresi linear berganda. Menurut Supranto (2010: 23), regresi linear berganda adalah metode analisis yang tepat dipergunakan kalau masalah penelitian (research problem) melibatkan satu variabel tak bebas $\mathrm{Y}$ yang metrik yang dipengaruhi atau terkait dengan lebih dari satu variabel bebas $\mathrm{X}$ yang metrik dan non-metrik. Tujuan analisis ini untuk memperkirakan/meramalkan nilai $\mathrm{Y}$, kalau semua variabel bebas $\mathrm{X}$ sudah diketahui nilainya, dengan menggunakan persamaan regresi linear berganda yang dibentuk dengan menggunakan metode kuadrat terkecil (least square method). Di samping itu juga untuk mengetahui besarnya pengaruh setiap variabel bebas yang terdapat dalam persamaan. Analisis data pada regresi linear berganda antara lain dengan uji simultan (uji F) dan uji parsial (uji t).

Uji $F$ adalah pengujian signifikansi persamaan yang digunakan untuk mengetahui seberapa besar pengaruh variabel independen (X1, X2, X3) secara bersama-sama terhadap variabel dependen (Y) yaitu produktifitas dengan langkah-langkah sebagai berikut:

1. Menentukan formulasi Ho dan Ha pada variabel independen $(\mathrm{X} 1, \mathrm{X} 2$, dan $\mathrm{X} 3)=$ 0 berarti tidak berpengaruh positif terhadap variabel dependen (Y).

2. Menentukan nilai kritis (F-tabel) dengan tingkat signifikansi adalah 5\% $(\alpha=0,05)$, sedangkan degree of freedom (df) pembilang sebesar $\mathrm{k}-2$ dan df untuk penyebut sebesar $\mathrm{n}-\mathrm{k}$ dimana $\mathrm{k}$ adalah jumlah variabel bebas dan $\mathrm{n}$ adalah jumlah sampel maka akan diperoleh nilai F-tabel.

Untuk uji t pada dasarnya menunjukkan seberapa jauh pengaruh satu variabel penjelas/independen secara individual dalam menerangkan variasi variabel dependen. Langkah-langkah pengujian sebagai berikut:

a. Menentukan formulasi Ho dan Ha pada masing-masing variabel independen $=0$ berarti masing-masing variabel independen $(\mathrm{X})$ tidak berpengaruh positif terhadap variabel dependen (Y).

Selanjutnya dilakukan analisis korelasi antar dimensi untuk mengetahui hubungan antar variabel. Aspek yang disorot dalam korelasi adalah apakah data sampel yang ada menyediakan bukti cukup bahwa ada kaitan antar variabel dan untuk mengetahui seberapa kuat hubungan antar variabel yang diteliti. Keeratan hubungan dinamakan koefisien 
Alienda Retnosari P. Pengaruh Kompensasi, Motivasi, Dan Lingkungan Kerja Terhadap ...

korelasi atau korelasi dengan pengukuran menggunakan Bivariate Pearson (Produk Momen Person). Menurut Supranto (2010: 10), hubungan $\mathrm{X}$ dan $\mathrm{Y}$ positif kalau kenaikan/penurunan $\mathrm{X}$ diikuti dengan kenaikan/penurunan $\mathrm{Y}$, sedangkan hubungan negatif kalau kenaikan/penurunan $\mathrm{X}$ diikuti kenaikan/penurunan Y.

\section{HASIL PENELITIAN DAN PEMBAHASAN}

\section{a. Profil Perusahaan}

Kantor Konsultan Pajak Drs. Lim Yung San dan Rekan bertempat di Springhills Office Tower Jalan Benyamin Syuaeb D/6 Kemayoran. Kantor ini merupakan perusahaan jasa yang khusus bergerak di bidang konsultasi pajak dengan berbekal tenaga profesional yang berkualitas dan pengalaman lebih dari 25 tahun menggeluti bidang konsultasi perpajakan. Perusahaan jasa ini mempunyai visi selalu memberikan pelayanan yang profesional agar dapat memberi nilai tambah bagi klien dan kelangsungan dari perusahaan. Adapun misi perusahaan yaitu menyediakan layanan konsultasi berkualitas terbaik terhadap klienklien secara profesional dan konsisten, menyediakan layanan konsultasi untuk menyelesaikan kasus dari klien secara komprehensif dan akurat sesuai dengan regulasi perpajakan yang ada, sebagai rekanan yang baik terhadap klien dan petugas pajak.

Sebagai konsultan pajak, perusahaan tersebut didukung professional di bidang accounting dan perpajakan dengan pelayanan jasa pembukuan pembuatan laporan keuangan bulanan dan tahunan, jasa pembuatan perhitungan pajak bulanan dan tahunan, dan konsultasi pajak. Sehingga jika ditarik pada struktur organisasi, Konsultan Pajak Drs. Lim Yung San dan Rekan dapat dilihat pada diagram berikut ini:

Gambar 1. Struktur Organisasi

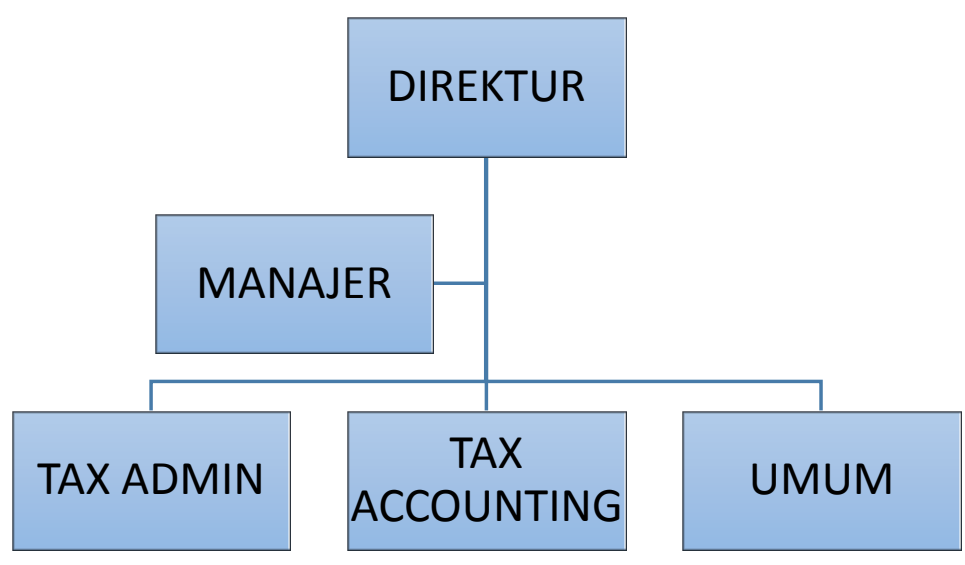

Tantangan bisnis bagi perusahaan konsultan pajak sendiri adalah soal integritas di tengah-tengah banyaknya kasus pajak seperti penyelundupan atau korupsi pajak. Hal ini memiliki potensi untuk bermain-main di dalamnya. Dengan demikian konsultan pajak yang diberikan kepada perusahaan maupun individu lebih bersifat layanan konsultasi di bidang perpajakan untuk bantuan dalam pengelolaan pajak yang baik dan benar baik yang bergerak di bidang manufaktur, perdagangan, jasa, pendidikan, lembaga keuangan, lembaga international, maupun pemerintah.

\section{b. Karakteristik Responden}

Hasil kuesioner yang disebarkan kepada 30 responden sebagai karyawan Kantor Konsultan Pajak Drs. Lim Yung San dan Rekan dihasilkan menurut jenis kelamin, usia, status karyawan, masa kerja dan tingkat pendidikan adalah responden berjenis kelamin perempuan/wanita lebih banyak dari responden laki-laki yaitu sebanyak $60 \%$ berjenis kelamin wanita dan $40 \%$ berjenis 
kelamin laki-laki. Sementara berdasarkan usia didominasi oleh responden memiliki presentase $27,67 \%$ untuk usia antara 20-30 tahun dan $33.73 \%$ yang berusia 31-50 tahun. Responden dengan status karyawan didominasi oleh status karyawan tetap dengan persentase $83,33 \%$ dan karyawan kontrak sebanyak 16,67\%. Adapun masa kerja responden didominasi oleh responden yang bekerja antara 6-25 tahun dengan presentase $66,67 \%$ dan $33,33 \%$ antara $0-5$ tahun lamanya bekerja. Terakhir untuk responden dengan karakteristik tingkat pendidikan didominasi oleh karyawan dengan lulusan S1/Sarjana sebanyak $76,67 \%$.

\section{c. Uji Kuesioner}

Hasil uji kuesioner dilakukan setelah seluruh data terkumpul sebagaimana adanya atau aslinya tanpa bermaksud untuk membuat kesimpulan yang berlaku secara umum. Kuesioner yang berhasil disebar kepada 30 responden terdiri dari 95 butir pertanyaan/pernyataan yang mewakili empat variabel yang diteliti yaitu variabel kompensasi (X1) yang terdiri dari 18 butir pernyataan, motivasi $(\mathrm{X} 2)$ yang terdiri dari 26 butir pernyataan, lingkungan kerja (X3) yang terdiri dari 25 butir pernyataan, dan terakhir variabel kepuasan kerja (Y) yang terdiri dari 26 butir pernyataan. Hasil analisis terhadap variabel kompensasi (X1) yang berhasil dirangkum memiliki mean terendah 3,21 dari indikator 'jaminan hari tua' dan mean tertinggi 3,94 dari indikator 'dana pensiun'. Sementara dari deskripsi statistik untuk menyajikan nilai terendah dan nilai tertinggi (maximum) atas indikator-indikator motivasi (X2) yaitu mean terendah 3,24 dari indikator 'pujian atas kontribusi bagi organisasi' dan mean tertinggi 4,71 dari indikator 'tugas yang menantang dan kemajuan'.

Adapun untuk deskripsi data pada variable lingkungan kerja (X3) merupakan deskripsi statistik yang menyajikan mean terendah 3,21 dari indikator 'kebisingan' dan mean tertinggi 4,18 dari indikator 'keamanan'. Terakhir untuk variabel kepuasan kerja (Y) dihasilkan memiliki mean terendah 3,35 dan mean tertinggi 4,41. Mean terendah tersebut merupakan indikator dari dimensi 'pekerjaan itu sendiri' sehingga dapat diketahui para karyawan tidak terlalu mengkhawatirkan prospek pengembangan diri maupun karir. Tetapi dilain sisi, mean tertinggi diperoleh dari dimensi supervisi dimana karyawan mengharapkan adanya dukungan moril bilamana mereka mengalami penurunan kepuasan kerja.

Untuk uji asumsi klasik yang dilakukan terbagi atas uji validitas yang menggunakan tingkat kepercayaan 95\%, dimana df $=\mathrm{n}-2$. Nilai n dalam penelitian ini yaitu 30 , sehingga nilai $\mathrm{df}=28$. Dengan begitu diperoleh nilai ttabel =1,6938. Selanjutnya dengan menggunakan rumus rtabel, maka diperoleh nilai rtabel $=0,2869$.

Dasar pengambilan keputusan pada uji validitas ini adalah sebagai berikut:

a. Jika rhitung $\geq 0,2869$, maka butir pertanyaan tersebut valid

b. Jika rhitung < 0,2869 maka butir pertanyaan tersebut tidak valid

Uji validitas diperoleh dari pernyataan kuesioner dengan 8 tidak valid yaitu kepuasan kerja pada butir pernyataan 9 dan 21 . Sedangkan kompensasi pada butir pernyataan 6 dan 10, motivasi pada butir 7 dan 22 dan lingkungan kerja pada butir 8 dan 14. Peneliti kemudian menghilangkan pernyataan tersebut agar penelitian tidak terhambat dan dapat dilanjutkan. Berdasarkan perhitungan atau pengujian validitas dari indikator pada seluruh variabel penelitian, hasilnya menunjukkan bahwa seluruh indikator dari variabel kompensasi, motivasi, lingkungan kerja dan kepuasan kerja pegawai mempunyai signifikansi hasil korelasi lebih kecil dari 0,05 (Sig. < 0,05), maka dapat disimpulkan seluruh indikator yang digunakan adalah valid dan layak untuk dianalisis lebih lanjut.

Kedua dilakukan uji reliabilitas
menunjukkan akurasi, ketepatan dan
konsistensi kuesioner dalam mengukur
variabel. Suatu kuesioner dinyatakan reliabel
atau handal apabila jawaban seseorang


Alienda Retnosari P. Pengaruh Kompensasi, Motivasi, Dan Lingkungan Kerja Terhadap ...

terhadap pertanyaan dan pernyataan adalah konsisten atau stabil dari waktu ke waktu. Pengujian reliabel dilakukan hanya pada indikator- indikator konstruk yang telah melalui pengujian validitas dan telah dinyatakan valid. Uji reliabilitas yang digunakan dalam program SPSS adalah uji statistic Cronbach Alpha. Suatu konstruk atau variabel dinyatakan reliabel apabila menghasilkan nilai Cronbach Alpha >0.60.

Tabel 1

Uji Reliabilitas

\begin{tabular}{|c|c|c|}
\hline Variabel & $\begin{array}{l}\text { Nilai Alpha } \quad(\alpha) \\
\text { Cronbach's }\end{array}$ & Keterangan \\
\hline Kepuasan Kerja (Y) & 0,955 & Reliabel \\
\hline Kompensasi (X1) & 0,889 & Reliabel \\
\hline Motivasi (X2) & 0,918 & Reliabel \\
\hline Lingkungan Kerja (X3) & 0,903 & Reliabel \\
\hline
\end{tabular}

Dari tabel di atas terlihat bahwa semua variabel dalam penelitian ini memiliki Cronbach's Alpha > 0.60 yang artinya semua variabel dinyatakan reliabel.

\section{d. Uji Asumsi Klasik}

Pertama dengan uji multikolonearitas. Uji ini bertujuan untuk melihat hubungan korelasi antar variabel bebas atau mengetahui ada atau tidaknya penyimpangan asumsi klasik multikoloniearitas yaitu adanya hubungan linear antar variabel independen dalam model regresi. Untuk mendeteksi ada atau tidaknya problem multikolinearitas pada model regresi adalah dengan melihat nilai yang direkomendasikan untuk VI (Variance Inflation Factor) <10. Hasil pengujian data multikolonearitas dapat dilihat sebagai berikut

Tabel 2

Coefficients $^{\mathrm{a}}$

\begin{tabular}{llll}
\hline Model & & \multicolumn{2}{c}{ Collinearity Statistics } \\
\cline { 3 - 4 } & & Tolerance & VIF \\
\hline 1 & Kompensasi & .621 & 1.611 \\
& Motivasi & .620 & 1.612 \\
& Lingkungan Kerja.646 & 1.547 \\
\hline
\end{tabular}

a. Dependent Variable: Kepuasan

Dapat diperoleh nilai VIF untuk semua variabel <10. Berdasarkan tabel tersebut terlihat nilai VIF dari variabel kompensasi terhadap variabel kepuasan kerja adalah sebesar 1,611, variabel motivasi terhadap variabel kepuasan kerja sebesar 1,612, kemudian variabel lingkungan kerja terhadap variabel kepuasan kerja adalah sebesar 1,547. Nilai VIF dari semua variabel independen adalah $<10$. Disimpulkan bahwa tidak terjadi multikolinearitas atau tidak terjadi hubungan korelasi antar variabel independen dan dapat disimpulkan bahwa data memenuhi uji asumsi klasik multikolinieritas.

Kedua uji heteroskedistisitas yang digunakan untuk mengetahui ada atau tidaknya penyimpangan asumsi klasik heteroskedastisitas yaitu adanya ketidaksamaan varian dari residual untuk semua pengamatan pada model regresi. Prasyarat yang harus terpenuhi dalam model regresi adalah tidak adanya gejala heteroskedastisitas. Hasil pengujian data heteroskedastisitas dapat dilihat pada tabel sebagai berikut: 


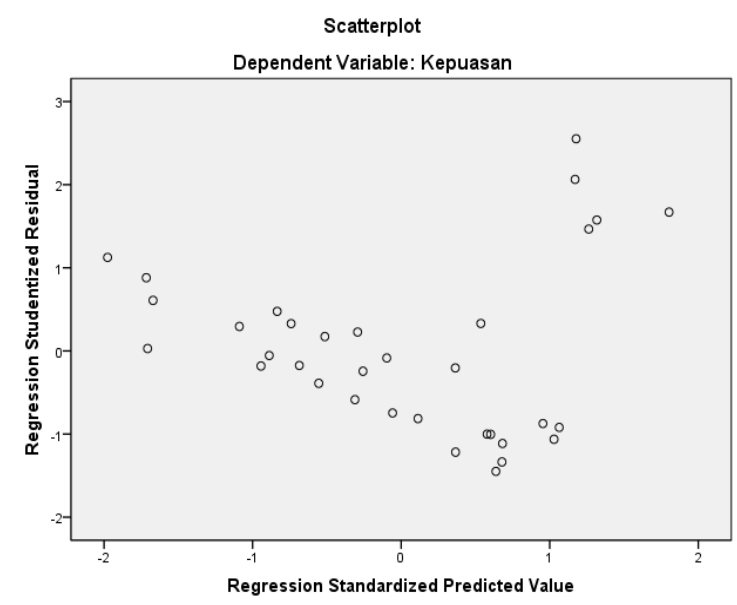

Gambar 2 Grafik Uji Heteroskedastisitas Kepuasan Kerja

Terakhir adalah uji normalitas yang dilakukan untuk mengetahui apakah populasi data terdistribusi normal. Uji normalitas untuk tiap variabel dilakukan dengan melihat titik sebaran data pada gambar grafik Q-Q plot. Data-data dari variabel dapat dikatakan normal, jika sebaran data berada pada garis lurus sebaran titik plot.

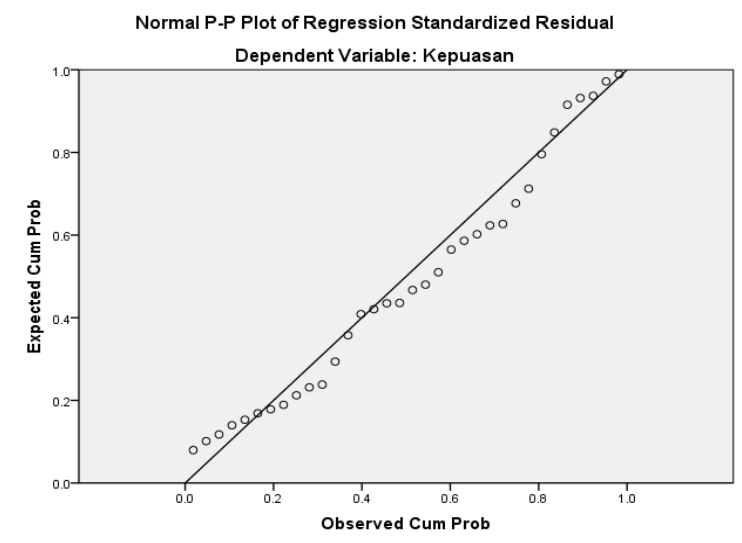

Gambar 3. Normalitas Plot

Garis diagonal dalam grafik ini menggambarkan keadaan ideal dari data yang mengikuti distribusi normal. Titik-titik di sekitar garis adalah keadaan data yang diuji. Kebanyakan titik-titik berada sangat dekat dengan garis atau bahkan menempel pada garis, maka dapat kita simpulkan jika data kita mengikuti distribusi normal.

\section{e. Uji Regresi Linier Berganda}

Setelah semua uji menunjukkan sesuai kriteria, maka selanjutnya dilakukan uji regresi linier berganda untuk mendapatkan persamaan regresinya. Model regresi dimaksud adalah $\mathrm{Y}=\mathrm{a}+\mathrm{b} 1 \mathrm{X} 1+\mathrm{b} 2 \mathrm{X} 2+$ b3X3. Hasil dari uji regresi linier berganda ditunjukkan oleh tabel dibawah ini:
Dari tabel di 3 maka didapatkan persamaan regresinya adalah:

$$
\mathrm{Y}=22.693+0.334 \mathrm{X} 1+0.331 \mathrm{X} 2+0.272 \mathrm{X} 3
$$

Keterangan:

$$
\begin{array}{ll}
\mathrm{Y} & =\text { Kepuasan Kerja } \\
\mathrm{X} 1 & =\text { Kompensasi } \\
\mathrm{X} 2 & =\text { Motivasi } \\
\mathrm{X} 3 & =\text { Lingkungan Kerja }
\end{array}
$$

Nilai konstanta 22.693 dengan taraf signifikasi $0.036 \quad$ (tidak signifikan) menyatakan bahwa jika tidak ada pengaruh dari unsur-unsur kompensasi, motivasi, dan lingkungan kerja maka perusahaan tidak akan berkembang. Hal ini disebabkan tidak adanya peningkatan kepuasan kerja karyawan di Kantor Konsultan Pajak Drs. Lim Yung San 
Alienda Retnosari P. Pengaruh Kompensasi, Motivasi, Dan Lingkungan Kerja Terhadap ...

dan Rekan. Koefisien regresi pada variabel kompensasi (X1) sebesar 0.334 adalah positif. Artinya setiap penambahan 1 (satu) unit nilai kompensasi akan meningkatkan kepuasan kerja karyawan sebesar 0.334 atau sebaliknya. Dapat juga diartikan semakin kompensasi sesuai maka akan semakin kuat peningkatan kepuasan kerja.

Sedangkan koefisien regresi pada variabel motivasi (X2) sebesar 0.331 adalah positif. Artinya setiap penambahan 1 (satu) unit nilai motivasi akan meningkatkan kepuasan kerja karyawan sebesar 0.331 atau sebaliknya. Atau semakin baik motivasi karyawan maka akan ada peningkatan kepuasan kerja di perusahaan. Koefisien regresi pada variabel lingkungan kerja (X3) sebesar 0.272 adalah positif. Artinya setiap penambahan 1 (satu) unit nilai lingkungan kerja akan meningkatkan kepuasan kerja karyawan sebesar 0.272 atau sebaliknya. Atau dapat juga diartikan semakin sesuai lingkungan kerja dengan harapan karyawan maka kepuasan kerja akan semakin naik. Namun untuk menguji signifikansi koefisien regresi tersebut masih diperlukan pengujian hipotesis menggunakan uji $\mathrm{t}$ dan uji $\mathrm{F}$ seperti yang tersaji berikut ini.

Berikutnya adalah uji koefisien determinasi (R2). Koefisien determinasi (R2) merupakan sumbangan (share) dari $\mathrm{X}$ terhadap variasi (naik turunnya) $\mathrm{Y}$, tingkat variasi ditunjukkan oleh besarnya varian $\mathrm{Y}$ (Supranto, 2010: 11).

Tabel 3 Koefisien Regresi Berganda

Coefficientsa

\begin{tabular}{|c|c|c|c|c|c|c|}
\hline \multirow[t]{2}{*}{ Mo } & & \multicolumn{2}{|c|}{$\begin{array}{l}\text { Unstandardized } \\
\text { Coefficients }\end{array}$} & \multicolumn{3}{|c|}{$\begin{array}{l}\text { Standardized } \\
\text { Coefficients } \\
\end{array}$} \\
\hline & & $\overline{\mathrm{B}}$ & Std. Error & Beta & $\mathrm{T}$ & Sig. \\
\hline \multirow[t]{4}{*}{1} & $\begin{array}{l}\text { (Constant) } \\
22.693\end{array}$ & & 10.352 & & 2.192 & .036 \\
\hline & $\begin{array}{l}\text { Kompensasi } \\
.334\end{array}$ & & .098 & .416 & 3.401 & .002 \\
\hline & $\begin{array}{l}\text { Motivasi } \\
.331\end{array}$ & & .136 & .298 & 2.436 & .021 \\
\hline & $\begin{array}{l}\text { Lingkungan Kerja } \\
.272\end{array}$ & & .106 & .307 & 2.562 & .016 \\
\hline
\end{tabular}

a. Dependent Variable: Kepuasan

Sumber : Data output SPSS versi 17 (2015)

Tabel 4

Analisis Koefisien Determinasi

Model Summary $^{\mathrm{b}}$

Model

Std. ErrorChange Statistics

R Adjusted Rof the R SquareF $\quad$ Sig.

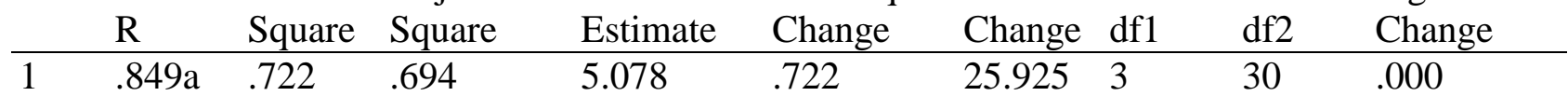

a. Predictors: (Constant), Lingkungan Kerja, Kompensasi, Motivasi

b. Dependent Variable: Kepuasan

Sumber: Data output SPSS versi 17 (2015)

Tabel 4, dapat dilihat bahwa nilai koefisien determinasi (R2) sebesar 0,722 hal ini berarti 72,2\% variabel dependen kepuasan kerja dapat dikatakan semakin kuat oleh 
variabel independen kompensasi, motivasi dan lingkungan kerja. Sedangkan sisanya sebesar yaitu 0,278 atau $27,8 \%$ dijelaskan oleh variabel lain yang tidak disertakan dalam model penelitian ini.

\section{Uji F}

Uji $F$ adalah pengujian signifikansi persamaan yang digunakan untuk mengetahui seberapa besar pengaruh variabel independen (X1, X2, X3) secara bersama-sama terhadap variabel dependen ( $\mathrm{Y}$ ) yaitu kepuasan kerja. Uji F dilakukan dengan cara membandingkan antara Fhitung dengan Ftabel. Dalam penelitian ini diperoleh hasil uji anova (uji F) sebagai berikut pada tabel 5 .

Hipotesis:

Ho : Secara simultan variabel kompensasi, motivasi dan lingkungan kerja tidak berpengaruh signifikan terhadap kepuasan kerja.
Ha : Secara simultan variabel kompensasi, motivasi dan lingkungan kerja berpengaruh signifikan terhadap kepuasan kerja.

Berdasarkan tabel 5 dapat dilihat nilai signifikannya (Sig.) adalah $0,000<0,05$ artinya Ho ditolak dan $\mathrm{Ha}$ diterima. Nilai Ftabel yang didapat dari perhitungan df $1=4$ $1=3$ dan df2 $=34-4=30$, dengan taraf signifikansi 0,05 maka didapat Ftabel $=2,92$. Dari Tabel 5.12 uji anova didapat Fhitung = 25,925 sehingga Ftabel < Fhitung $(2,92<$ $25,925)$ yang berarti juga Ho ditolak dan $\mathrm{Ha}$ diterima.

Berdasarkan dua keterangan di atas maka dapat dinyatakan bahwa variabel kompensasi, motivasi dan lingkungan kerja secara simultan berpengaruh signifikan terhadap kepuasan kerja di Kantor Konsultan Pajak Drs. Lim Yung San dan Rekan.

Tabel 5

Hasil Uji F-Simultan

\begin{tabular}{lllllll}
\hline \multicolumn{2}{l}{ ANOVAb } & \multicolumn{5}{l}{} \\
\hline Model & & Sum of Squares & Df & Mean Square & F & Sig. \\
\hline 1 & Regression & 2005.392 & 3 & 668.464 & 25.925 & $.000 \mathrm{a}$ \\
& Residual & 773.549 & 30 & 25.785 & & \\
& Total & 2778.941 & 33 & & & \\
\hline
\end{tabular}

a. Predictors: (Constant), Lingkungan Kerja, Kompensasi, Motivasi

b. Dependent Variable: Kepuasan

Sumber : Data output SPSS versi 17 (2015)

\section{Uji t}

Uji t digunakan untuk menguji pengaruh variabel kompensasi, motivasi dan lingkungan kerja secara parsial terhadap variabel kepuasan kerja karyawan. Hasil pengujian disajikan pada Tabel 5.3

a. Uji Parsial Kompensasi terhadap Kepuasan kerja Karyawan.

Hipotesa 1 : Kompensasi

berpengaruh signifikan terhadap kepuasan kerja karyawan.

Ho : Kompensasi tidak berpengaruh signifikan secara parsial terhadap kepuasan kerja karyawan.
Ha : Kompensasi berpengaruh signifikan secara parsial terhadap kepuasan kerja karyawan.

Dengan cara pengambilan keputusan:

Jika signifikan (Sig.) > 0,05 atau thitung $<$ ttabel maka Ho diterima

Jika signifikan (Sig.) $<0,05$ atau thitung $>$ ttabel maka Ho ditolak

Hasil diketahui skor thitung untuk variabel kompensasi sebesar 3,401. Nilai ttabel dilihat dari derajat bebas $(\mathrm{df}=\mathrm{n}-2)$ yaitu 2,036. Maka diperoleh thitung $>$ ttabel $(3,401>2,036)$. Kemudian, nilai signifikan pada variabel kompensasi adalah 0,002 < 0,05 . Sehingga dapat disimpulkan bahwa $\mathrm{Ha}$ 
Alienda Retnosari P. Pengaruh Kompensasi, Motivasi, Dan Lingkungan Kerja Terhadap ...

diterima dan Ho ditolak. Artinya, variabel kompensasi berpengaruh signifikan secara parsial terhadap kepuasan kerja karyawan.

b. Uji Parsial Motivasi terhadap Kepuasan kerja Karyawan

Hipotesa 2 : Motivasi berpengaruh signifikan terhadap kepuasan kerja karyawan.

Ho : Motivasi tidak berpengaruh signifikan secara parsial terhadap kepuasan kerja karyawan.

Ha : Motivasi berpengaruh signifikan secara parsial terhadap kepuasan kerja karyawan.

Dengan cara pengambilan keputusan:

Jika signifikan (Sig.) > 0,05 atau thitung $<$ ttabel maka Ho diterima

Jika signifikan (Sig.) $<0,05$ atau thitung $>$ ttabel maka Ho ditolak

Diketahui skor thitung untuk variabel motivasi sebesar 2,436. Nilai ttabel dilihat dari derajat bebas (df $=\mathrm{n}-2$ ) yaitu 2,036. Maka diperoleh thitung > ttabel $(2,436>$ 2,036). Kemudian, nilai signifikan pada variabel motivasi adalah $0,021<0,05$. Sehingga dapat disimpulkan bahwa $\mathrm{Ha}$ diterima dan Ho ditolak. Artinya, variabel motivasi berpengaruh signifikan secara parsial terhadap kepuasan kerja karyawan.

c. Uji Parsial Lingkungan Kerja terhadap Kepuasan kerja Karyawan

Hipotesa 3 : Lingkungan kerja berpengaruh signifikan terhadap kepuasan kerja karyawan.

Ho : Lingkungan kerja tidak berpengaruh signifikan secara parsial terhadap kepuasan kerja karyawan.

$\mathrm{Ha}$ : Lingkungan kerja berpengaruh signifikan secara parsial terhadap kepuasan kerja karyawan.

Dengan cara pengambilan keputusan:

Jika signifikan (Sig.) > 0,05 atau thitung $<$ ttabel maka Ho diterima

Jika signifikan (Sig.) $<0,05$ atau thitung $>$ ttabel maka Ho ditolak

Diketahui skor thitung untuk variabel lingkungan kerja sebesar 2,562. Nilai ttabel dilihat dari derajat bebas $(\mathrm{df}=\mathrm{n}-2)$ yaitu
2,036. Maka diperoleh thitung > ttabel atau 2,562 > 2,036. Kemudian, nilai signifikan (Sig.) pada variabel lingkungan kerja adalah $0,016<0,05$. Sehingga dapat disimpulkan bahwa Ho ditolak dan Ha diterima. Artinya, variabel lingkungan kerja berpengaruh signifikan secara parsial terhadap kepuasan kerja karyawan.

\section{Hasil Uji Korelasi Antar Dimensi}

Penulis akan menyimpulkan hasil perhitungan koefisien korelasi (r) untuk mengetahui dimensi variabel independen yang berpengaruh paling dominan terhadap dimensi variabel dependen. Semakin besar nilai pearson correlation (r) maka semakin kuat hubungannya dan pengaruhnya besar terhadap peningkatan dimensi dari variabel dependennya. Sebagai bahan acuan untuk mengetahui tingkat hubungan antar dimensi digunakan tabel tingkat hubungan berdasarkan koefisien interval yang dikutip dari Jonathan (2006: 66).

Korelasi Antar Dimensi Variabel Kompensasi (X1) dengan Kepuasan Kerja (Y)

Tabel 7, dapat dilihat bahwa hasil uji korelasi antar dimensi dari variabel kompensasi (X1) terhadap variabel kepuasan kerja (Y) didapatkan nilai yang terendah terdapat pada hubungan dimensi kompensasi langsung terhadap dimensi rekan kerja yaitu sebesar 0.430 yang berarti tingkat hubungan antar kedua dimensi ini dinilai moderat dan nilai yang terbesar ada pada korelasi dimensi kompensasi tidak langsung terhadap dimensi pengawasan/supervisi yaitu sebesar 0,710 yang berarti tingkat hubungan antar kedua dimensi tersebut dinilai sangat kuat berdasarkan standar nilai Pearson Correlation (R).

Hasil penelitian menyimpulkan bahwa variabel kompensasi berpengaruh signifikan secara parsial terhadap kepuasan kerja karyawan. Pernyataan ini telah dibuktikan dengan nilai thitung $>$ ttabel $(3,401>2,036)$ dengan nilai signifikan (Sig.) pada variabel kompensasi adalah 0,002 $<0,05$ sehingga dapat disimpulkan bahwa Ha diterima dan Ho ditolak yang artinya variabel kompensasi 
berpengaruh signifikan secara parsial terhadap kepuasan kerja karyawan.

Hal ini sejalan dengan penelitian terdahulu dalam jurnal The Effects of Reward System and Motivation on Job Satisfaction:'Evidence from the Education Industry in Malaysia' pada tahun 2013 oleh Anantha Raj A. Arokiasamy, Huam Hon Tat dan Abdul Ghani Kanesan bin Abdullah. Hasil penelitian mereka menunjukkan bahwa ada hubungan positif yang signifikan antara kompensasi, motivasi dan promosi dan kepuasan kerja.

Menurut Handoko (2001), kompensasi merupakan segala sesuatu yang diterima para karyawan sebagai balas jasa untuk mereka. Bila perumusan kebijaksanaan kompensasi tepat baik dalam aspek keadilan maka karyawan akan merasa puas untuk melaksanakan berbagai kegiatan yang berhubungan dengan pencapaian perusahaan. Penelitian ini menyimpulkan bahwa pemberian kompensasi merupakan fungsi strategik sumber daya manusia yang mempunyai imbas signifikan atas fungsifungsi sumberdaya manusia lainnya. Hal ini memberikan implikasi bahwa pihak Kantor Konsultan Pajak Drs. Lim Yung San dan Rekan hendaknya mampu memberikan kompensasi yang menarik serta kompetitif, sesuai dengan kapasitas dan kompentensi karyawan karena kompensasi mempengaruhi keseluruhan strategi perusahaan yang memberi dampak pada kepuasan kerja, keterikatan karyawan, produktivitas, mutasi dan rotasi karyawan, serta proses-proses lainnya di dalam sebuah organisasi.

Tabel 6

Interpretasi Koefisien Korelasi Nilai $r$

\begin{tabular}{ll}
\hline Interval Koefisien & Tingkat Hubungan \\
\hline $0,00-0,25$ & X dan Y korelasi sangat lemah \\
$0,25-0,50$ & X dan Y korelasi moderat \\
$0,50-0,75$ & X dan Y korelasi kuat \\
$0,75-1,00$ & X dan Y korelasi sangat kuat \\
\hline
\end{tabular}

Sumber : Jonathan (2006: 66)

Hasil perhitungan koefisien korelasi (r) antar dimensi dapat dilihat pada korelasi berikut ini:

Tabel 7

Hasil Uji Korelasi Antar Dimensi

\begin{tabular}{|c|c|c|c|c|c|c|}
\hline \multirow[b]{2}{*}{ Variabel } & \multirow[b]{2}{*}{ Dimensi } & \multicolumn{5}{|c|}{ Variabel Kepuasan Kerja } \\
\hline & & Gaji & Promosi & $\begin{array}{l}\text { Pekerjaan itu } \\
\text { sendiri }\end{array}$ & Rekan kerja & $\begin{array}{l}\text { Pengawasa } \\
\mathrm{n} /\end{array}$ \\
\hline \multirow[t]{2}{*}{ Kompensasi } & Kompensasi langsung & 0.462 & 0.465 & 0.433 & 0.430 & 0.616 \\
\hline & $\begin{array}{l}\text { Kompensasi tidak } \\
\text { langsung }\end{array}$ & 0.665 & 0.601 & 0.668 & 0.617 & 0.710 \\
\hline \multirow[t]{5}{*}{ Motivasi } & Kebutuhan fisiologis & 0.588 & 0.632 & 0.366 & 0.566 & 0.423 \\
\hline & Kebutuhan rasa aman & 0.661 & 0.513 & 0.602 & 0.649 & 0.481 \\
\hline & Kebutuhan social & 0.660 & 0.479 & 0.349 & 0.661 & 0.492 \\
\hline & Kebutuhan penghargaan & 0.758 & 0.677 & 0.630 & 0.692 & 0.570 \\
\hline & $\begin{array}{l}\text { Kebutuhan aktualisas } \\
\text { diri }\end{array}$ & i 0.374 & 0.466 & 0.343 & 0.315 & 0.369 \\
\hline
\end{tabular}


Alienda Retnosari P. Pengaruh Kompensasi, Motivasi, Dan Lingkungan Kerja Terhadap ...

\begin{tabular}{|c|c|c|c|c|c|c|}
\hline $\begin{array}{l}\text { Lingkungan } \\
\text { Kerja }\end{array}$ & $\begin{array}{l}\text { Lingkungan kerja fisik } \\
\text { Lingkungan kerja no } \\
\text { fisik }\end{array}$ & $\begin{array}{l}0.520 \\
0.702\end{array}$ & $\begin{array}{l}0.471 \\
0.490\end{array}$ & $\begin{array}{l}0.541 \\
0.389\end{array}$ & $\begin{array}{l}0.606 \\
0.757\end{array}$ & $\begin{array}{l}0.479 \\
0.514\end{array}$ \\
\hline
\end{tabular}

Sumber : Data Primer Yang Diolah (2015)

Korelasi Antar Dimensi Variabel Motivasi

(X2) Terhadap Kepuasan Kerja (Y).

Tabel 7, dapat dilihat bahwa hasil uji korelasi antar dimensi dari variabel motivasi (X2) terhadap variabel kepuasan kerja (Y) didapatkan nilai yang terendah terdapat pada hubungan dimensi aktualisasi diri terhadap dimensi rekan kerja yaitu sebesar 0.315 yang berarti tingkat hubungan antar kedua dimensi ini dinilai moderat dan nilai yang terbesar ada pada korelasi dimensi penghargaan terhadap dimensi gaji yaitu sebesar 0,758 yang berarti tingkat hubungan antar kedua dimensi tersebut dinilai sangat kuat berdasarkan standar nilai Pearson Correlation (R).

Hasil penelitian menyimpulkan bahwa variabel motivasi berpengaruh signifikan secara parsial terhadap kepuasan kerja karyawan yang diketahui dari hasil perhitungan thitung $>$ ttabel $(2,436>2,036)$ dengan nilai signifikan pada variabel motivasi adalah $0,021<0,05$. Sehingga dapat disimpulkan bahwa $\mathrm{Ha}$ diterima dan $\mathrm{Ho}$ ditolak yang artinya variabel motivasi berpengaruh signifikan secara parsial terhadap kepuasan kerja karyawan. Hal ini sejalan dengan penelitian terdahulu dalam jurnal Work Motivation: Relationships with Job Satisfaction, Locus of Control and Motivation oleh Tiiu Kamdron, $\mathrm{PhD}$ pada tahun 2015 yang memuat bahwa ada hubungan yang kuat antara tingkat motivasi kerja dan kepuasan kerja.

Motivasi menjelaskan intensitas, arah dan ketekunan seorang individu untuk mencapai tujuan. Hasibuan (2003) juga menyebutkan bahwa motivasi merupakan dorongan karyawan atau sikap mental karyawan yang mengarah atau mendorong perilaku kearah pencapaiaan kebutuhan yang memberikan kepuasan. Dengan demikian, diperlukan peran atasan di Kantor Konsultan
Pajak Drs. Lim Yung San dan Rekan dalam mencermati secara sistematis perkembangan karyawannya sehingga dapat meningkatkan perilaku kerja karyawan untuk bekerja lebih giat dalam sebuah perusahaan dan mencapai kepuasan kerja yang terbaik.

Korelasi Antar Dimensi Variabel Lingkungan Kerja (X3) Terhadap Kepuasan Kerja (Y).

Tabel 7, dapat dilihat bahwa hasil uji korelasi antar dimensi dari variabel lingkungan kerja (X3) terhadap variabel kepuasan kerja (Y) didapatkan nilai yang terendah terdapat pada hubungan dimensi lingkungan kerja non fisik terhadap dimensi pekerjaan itu sendiri yaitu sebesar 0.389 yang berarti tingkat hubungan antar kedua dimensi ini dinilai moderat dan nilai yang terbesar ada pada korelasi dimensi lingkungan kerja non fisik terhadap dimensi rekan kerja yaitu sebesar 0.757 yang berarti tingkat hubungan antar kedua dimensi tersebut dinilai kuat berdasarkan standar nilai Pearson Correlation (R).

Hasil perhitungan variabel lingkungan kerja pada kepuasan kerja menunjukkan thitung > ttabel atau 2,562> 2,036 dengan nilai signifikan (Sig.) pada variabel lingkungan kerja adalah $0,016<0,05$. Sehingga dapat disimpulkan bahwa Ho ditolak dan Ha diterima. Artinya, variabel lingkungan kerja berpengaruh signifikan secara parsial terhadap kepuasan kerja karyawan. Hal ini sejalan dengan penelitian terdahulu dalam jurnal Influences Of Work Behavior, Work Environment And Motivation In Clove Cigarette Factories In Kudus (Indonesia) oleh Dr. Musriha pada 2011. Didalam jurnal tersebut disebutkan bahwa model hubungan antara variabel yang diteliti yakni perilaku kerja, lingkungan kerja dan motivasi pekerjaan secara signifikan 
berkorelasi dengan kepuasan kerja dan prestasi kerja.

Lingkungan kerja mempunyai pengaruh langsung terhadap para karyawan yang melaksanakan proses produksi. Hal tersebut sejalan dengan Rivai (2004), yang mengatakan lingkungan kerja merupakan elemen-elemen organisasi sebagai sistem sosial yang mempunyai pengaruh yang kuat di dalam pembentukan perilaku individu pada organisasi dan berpengaruh terhadap prestasi organisasi. Dengan demikian diharapkan, Kantor Konsultan Pajak Drs. Lim Yung San dan Rekan dapat lebih mengakomodasi keadaan/kondisi lingkungan sekitar karyawannya bekerja kondusif, seperti lingkungan fisik dan non fisik yang menunjang kinerja, metode kerja, serta pengaturan kerja baik keseluruhan alat perkakas dan bahan yang dihadapi. Terjaminnya para karyawan saat bekerja melaksanakan tugasnya dalam keadaan yang memenuhi persyaratan, maka dapat dipastikan karyawan dapat melakukan tugasnya tanpa mengalami hambatan.

Pengaruh Kompensasi, Motivasi, dan Lingkungan Kerja terhadap Kepuasan Kerja Karyawan

Hasil perhitungan variabel pengaruh kompensasi, motivasi, dan lingkungan kerja terhadap kepuasan kerja karyawan menunjukkan nilai Ftabel yang didapat dari perhitungan df1=4-1=3 dan df2=34-4=30, dengan taraf signifikansi 0,05 maka didapat Ftabel $=2,92$. Dari Tabel 5.12 uji anova didapat Fhitung $=25,925$ sehingga Ftabel < Fhitung $(2,92<25,925)$ yang berarti juga Ho ditolak dan $\mathrm{Ha}$ diterima. Berdasarkan dua keterangan diatas maka dapat dinyatakan bahwa variabel kompensasi, motivasi dan lingkungan kerja secara simultan berpengaruh signifikan terhadap kepuasan kerja di Kantor Konsultan Pajak Drs. Lim Yung San dan Rekan.

Sejalan dengan temuan diatas, hasil penelitian dari Sajid Tufail dan Muhammad Sajid (2015) mengenai An Empirical Study of Relationship between Compensation,
Working Environment and Motivation of Employees in Banking Sector of Pakistan menyebutkan bahwa diketahui adanya hubungan yang signifikan dan positif melalui struktur kompensasi yang memuaskan, peningkatan motivasi, dan lingkungan kerja yang baik.

Menurut Stephen P. Robbins (2000), beberapa hal penting yang dapat mendukung kepuasan kerja yaitu pekerjaan secara mental menantang, balas jasa dan penghargaan yang sesuai dengan harapan, lingkungan kerja yang kondusif, rekan kerja yang mendukung. Pihak kantor konsultan hendaknya dapat memperhatikan faktor tersebut. Ketika semua tugas tersebut terselesaikan, karyawan akan mendapatkan imbalan yang seimbang dengan usaha yang telah dilakukan karyawan dan karyawan akan merasakan kepuasan kerja. Terlebih apabila perusahaan memotivasi dan memperhatian agar karyawan dapat berkontribusi lebih baik serta diberikan kesempatan untuk menduduki jabatan yang lebih tinggi.

\section{SIMPULAN DAN SARAN Simpulan}

Berdasarkan hasil analisis dan pembahasan yang telah dilakukan sebelumnya, maka dari penelitian ini dapat ditarik kesimpulan sebagai berikut:

1. Variabel kompensasi (X1) berpengaruh positif dan signifikan terhadap kepuasan kerja karyawan (Y) artinya semakin tinggi kompensasi yang diberikan, maka semakin tinggi kepuasan kerja karyawan, sehingga hipotesis pertama yang diajukan dapat diterima.

2. Variabel motivasi (X2) berpengaruh positif dan signifikan terhadap kepuasan kerja karyawan (Y), artinya semakin baik motivasi maka semakin tinggi pula kepuasan kerja karyawan, sehingga hipotesis kedua yang diajukan dapat diterima.

3. Variabel lingkungan kerja (X3) berpengaruh positif dan signifikan terhadap kepuasan kerja karyawan (Y), artinya semakin baik kondisi lingkungan 
Alienda Retnosari P. Pengaruh Kompensasi, Motivasi, Dan Lingkungan Kerja Terhadap ...

kerja maka semakin baik pula kepuasan kerja karyawan sehingga hipotesis ketiga yang diajukan dapat diterima.

4. Variabel kompensasi (X1), motivasi (X2) dan lingkungan kerja (X3) secara simultan berpengaruh positif dan signifikan terhadap kepuasan kerja karyawan (Y), sehingga hipotesis keempat yang diajukan dapat diterima.

\section{Saran}

Adapun saran yang berupa rekomendasi yang relevan sesuai hasil penelitian untuk meningkatkan kepuasan kerja karyawan, yaitu:

1. Berdasarkan uji korelasi antar dimensi variabel kompensasi terdapat hasil dengan tingkat korelasi terkuat ada pada korelasi dimensi kompensasi tidak langsung terhadap dimensi pengawasan/supervisi. Implikasinya bahwa jika Kantor Konsultan Pajak Drs. Lim Yung San dan Rekan mampu meningkatkan kompensasi tidak langsung maka diharapkan dapat meningkatkan pengawasan/supervisi dalam mencapai kepuasan karyawan. Adapun indikator kompensasi tidak langsung yang dapat ditingkatkan lagi oleh manajemen seperti jaminan social, jaminan hidup kesehatan, liburan khusus, cuti, dana pension, dan asuransi hari tua.

2. Berdasarkan uji korelasi antar dimensi variabel motivasi terdapat hasil dengan tingkat korelasi terkuat ada pada korelasi dimensi kebutuhan penghargaan terhadap dimensi gaji. Implikasinya bahwa jika Kantor Konsultan Pajak Drs. Lim Yung San dan Rekan mampu meningkatkan penghargaan maka diharapkan dapat meningkatkan jumlah gaji karyawan dalam mencapai kepuasan kerja. Adapun indikator kebutuhan penghargaan yang dapat ditingkatkan lagi oleh manajemen seperti perhargaan atas kesan diri yang positif dan pujian atas kontribusi bagi organisasi.

3. Berdasarkan uji korelasi antar dimensi variabel lingkungan kerja terdapat hasil dengan tingkat korelasi terkuat ada pada korelasi dimensi lingkungan kerja non fisik terhadap dimensi rekan kerja. Implikasinya bahwa jika Kantor Konsultan Pajak Drs. Lim Yung San dan Rekan mampu meningkatkan kualitas lingkungan kerja non fisik maka diharapkan dapat meningkatkan kualitas hubungan antar karyawan atau sesama rekan kerja dalam mencapai kepuasan kerja. Adapun indikator lingkungan kerja non fisik yang dapat ditingkatkan lagi oleh manajemen yakni hubungan social di tempat kerja antara atasan dengan bawahan dan sebaliknya.

4. Penelitian selanjutnya yang serupa diharapkan dapat meneliti faktor lain diluar penelitian ini agar dapat diketahui ada penyebab faktor lain lagi seperti disiplin kerja, gaya kepemimpinan, produktivitas, pelatihan, dan lain-lain yang mempengaruhi kinerja karyawan di Kantor Konsultan Pajak Drs. Lim Yung San dan Rekan.

\section{DAFTAR PUSTAKA}

Nitisemito, Alex S. (2000). "Manajemen Personalia: Manajemen Sumber Daya Manusia. Ed 3. Ghalia Indonesia. Jakarta

Ali, Asghar and Muhammad Naseem Akram. (2012). "Impact of Financial Rewards on Employee's Motivation and Satisfaction in Pharmaceutical Industry". Global Journal of Management and Business Research Vol.12 Publisher: Global Journals Inc. ISSN: 2249-4588. Pakistan

Arokiasamy, Anantha Raj A, Huam Hon Tat and Abdul Ghani Kanesan bin Abdullah. (2013). "The Effects of Reward System and Motivation on Job Satisfaction: Evidence from the Education Industry in Malaysia". World Applied Sciences Journal 24 (12): 1597-1604, 2013 ISSN 1818-4952, IDOSI Publications.

Daft, L. Richard. (2006). "Management". Salemba Empat. Denpasar: Astabrata Bali. Jakarta 
Dessler, Gary. (2005). "Manajemen Sumber Daya Manusia". Alih bahasa: Eli Tanya. Penyunting Bahasa: Budi Supriyanto. Jakarta

Gorda, I Gusti Ngurah.. (2006). "Manajemen Sumber Daya Manusia". cetakan ketiga.

Greenberg, Jerald and Robert Baron. (2003). "Behavior in Organizations (Understanding And Managing The Human Side Of Work)". Eight edition. Prentice Hall

Handoko, T.H. (2001). "Manajemen Personalia dan Sumber Daya Manusia". BPFE Press. Yogyakarta

Hasibuan, Malayu S.P. (2008). "Manajemen Sumber Daya Manusia. Edisi Revisi". PT. Bumi Aksara. Jakarta

Hasibuan, SP. M. (2007). "Manajemen Sumber Daya Manusia. Edisi Revisi". Cetakan kesepuluh. Jakarta: Bumi Aksara.

Luthans, Fred. (2011). "Organizational Behavior An Evidence-Based Approach". Twelfth Edition. McGrawHill/Irwin. New York

Malayu, S.P Hasibuan. (2001). "Sumber Daya Manusia”. Cet. Ke-4. Bumi Aksara: Jakarta.

Mangkunegara, A. Anwar Prabu. (2002). "Manajemen Sumber Daya Manusia Perusahaan". PT. Remaja Rosdakarya. Bandung

Mangku Negara, A.A.Anwar Prabu. (2006). Evaluasi Kinerja SDM. Cetakan kedua.

Mello, Jeffrey A. (2002). "Strategic Human Resource Management". South-Western. USA

Milkovich, G.T. \& Newman. J.M. (2002). "Compensation" (7th ed.). McGraw-Hill. New York

Mondy, R. Wayne. Robert M. Noe and Shane R. Premeaux. (2003). "Human Resource Management". Fifth Edition. Allyn and Bacon. Massachusetts

Nazir, Wang Qun, and Muhammad Naseer Akhtar. (2015). "Financial Rewards Climate And Its Impact On Employee Attitudes Towards Job Satisfaction In The Retail Organizations". European
Scientific Journal. vol.11, No.1, ISSN: 1857 - 7881. China

Richard L. Daft. (2000) "Manajemen". Erlangga. Jakarta

Robbins dan Coulter. (2010). "Manajemen". Erlangga. Jakarta

Robbins, Judge. (2007). "Perilaku Organisasi". Buku 1 dan 2. Salemba Empat. Jakarta

Robbins, Stephen P.-Timothy A. Judge. (2008). "Perilaku Organisasi". Edisi 2- Buku 1. Salemba Empat. Jakarta.

Robert L. Malthis dan Jhon H. Jackson. (2000). "Manajemen Sumber Daya Manusia". Buku 1. Salemba 4. Jakarta

Samsuddin, Sadili. (2006). "Manajemen Sumber Daya Manusia". Pustaka Setia. Bandung.

Sedarmayanti. (2007). "Sumber Daya Manusia dan Produktivitas Kerja". Mandar Maju: Bandung.

Simamora, Henry. (2006). "Manajemen Sumber Daya Manusia". Cetakan Kedua. STIE YKPN. Yogyakarta

Stephen, P. Robbins. (2000). "Essential of Organizational Behavior". 6th Edition. Prentice-Hall. New Jersey

Stephen, P. Robbins. (2000). "Essential of Organizational Behavior". 6th Edition. Prentice-Hall. New Jersey

Terry, R George. (2009). "Prinsip-Prinsip Manajemen". Bumi Aksara. Jakarta

Wursanto, I. (2003). "Dasar-Dasar Ilmu Organisasi". Andi Offset. Yogyakarta 